University of Nebraska - Lincoln

DigitalCommons@University of Nebraska - Lincoln

2000

Relation of Pathways and Transit Times of Recharge Water to

Nitrate Concentrations Using Stable Isotopes

\author{
Matthew K. Landon \\ US Geological Survey \\ Geoffrey N. Delin \\ US Geological Survey \\ Stephen C. Komor \\ US Geological Survey \\ Charles P. Regan \\ Minnesota Pollution Control Agency
}

Follow this and additional works at: https://digitalcommons.unl.edu/usgsstaffpub

Part of the Earth Sciences Commons

Landon, Matthew K.; Delin, Geoffrey N.; Komor, Stephen C.; and Regan, Charles P., "Relation of Pathways and Transit Times of Recharge Water to Nitrate Concentrations Using Stable Isotopes" (2000). USGS Staff -- Published Research. 221.

https://digitalcommons.unl.edu/usgsstaffpub/221

This Article is brought to you for free and open access by the US Geological Survey at DigitalCommons@University of Nebraska - Lincoln. It has been accepted for inclusion in USGS Staff -- Published Research by an authorized administrator of DigitalCommons@University of Nebraska - Lincoln. 


\title{
Relation of Pathways and Transit Times of Recharge Water to Nitrate Concentrations Using Stable Isotopes
}

\author{
by Matthew K. Landon a,d, Geoffrey N. Delin ${ }^{a}$, Stephen C. Komor ${ }^{\mathrm{b}}$, and Charles P. Regan
}

\begin{abstract}
Oxygen and hydrogen stable isotope values of precipitation, irrigation water, soil water, and ground water were used with soilmoisture contents and water levels to estimate transit times and pathways of recharge water in the unsaturated zone of a sand and gravel aquifer. Nitrate-nitrogen (nitrate) concentrations in ground water were also measured to assess their relation to seasonal recharge. Stable isotope values indicated that recharge water usually had a transit time through the unsaturated zone of several weeks to months. However, wetting fronts usually moved through the unsaturated zone in hours to weeks. The much slower transit of isotopic signals than that of wetting fronts indicates that recharge was predominantly composed of older soil water that was displaced downward by more recent infiltrating water. Comparison of observed and simulated isotopic values from pure-piston flow and mixing-cell water and isotope mass balance models indicates that soil water isotopic values were usually highly mixed. Thus, movement of recharge water did not occur following a pure piston-flow displacement model but rather follows a hydrid model involving displacement of mixed older soil water with new infiltration water. An exception to this model occurred in a topographic depression, where movement of water along preferential flowpaths to the water table occurred within hours to days following spring thaw as result of depression-focused infiltration of snow melt. In an adjacent upland area, recharge of snow melt occurred one to two months later. Increases in nitrate concentrations at the water table during April-May 1993 and 1994 in a topographic lowland within a corn field were related to recharge of water that had infiltrated the previous summer and was displaced from the unsaturated zone by spring infiltration. Increases in nitrate concentrations also occurred during July-August 1994 in response to recharge of water that infiltrated during May-August 1994. These results indicate that the largest ground water nitrate concentrations were associated with recharge of water that infiltrated into the soil during May-August, when most nitrogen fertilizer was applied.
\end{abstract}

\section{Introduction}

Surficial sand and gravel aquifers are recharged primarily by infiltration of precipitation and are vulnerable to contamination by chemicals leached through soils. Contamination of shallow ground water with nitrate nitrogen (nitrate) from agricultural fertilizers, animal waste, or septic systems is a widely documented problem (Hallberg 1989; Fedkiw 1991; Puckett 1995). Because chemical reactions that affect solutes are time dependent, the transit time of water in the unsaturated zone of sand and gravel aquifers can be a critical factor in determining solute concentrations in recharge water (Bowman and Rice 1986; Gamble et al. 1990a, 1990b).

The relation of solute concentration to transit time of recharge water is strongly affected by the pathways of water in the unsaturated zone. Water that moves rapidly along preferential flowpaths may be relatively unaffected by reactions with soil or mixing with

'U.S. Geological Survey, 2280 Woodale Dr., Mounds View, MN 55112

bU.S. Geological Survey, 903 Hanshaw Rd., Ithaca, NY 14850

"Minnesota Pollution Control Agency, 520 Lafayette Rd., St. Paul, MN 55155

${ }^{d}$ Corresponding author. Present address: U.S. Geological Survey, 100 Centennial Mall N., Rm. 406 Federal Bldg., Lincoln, NE 68508; (402) 437. 5836; fax (402) 437-5139; landon@usgs.gov

Received June 1999, accepted November 1999 other soil water, whereas water that moves more slowly through the soil matrix may be greatly affected by such reactions. In addition, ground water recharge rates vary considerably due to topography (Meyboom 1966; Miller et al. 1985; Fortin et al. 1991), soil properties, and vegetation types (Sharma et al. 1983). Transit times and pathways of recharge water will also be affected by these physical factors. Knowledge of the transit times and pathways of recharge water in different topographic and land-use areas is necessary to understand the quantity and timing of solute movement to unconfined sand and gravel aquifers.

This paper presents the results of data collection during 1993-94 at a research site in a sand-plain setting in east-central Minnesota (Figure 1). The objectives of the study were (1) to determine the transit times and pathways of recharge water within the unsaturated zone in different land use and topographic settings, and (2) to relate nitrate concentrations in ground water to recharge. This study was carried out in conjunction with studies assessing focused recharge of water and agricultural chemicals in topographic depressions (Delin and Landon 1996; Delin et al. 1996, in press). For this study, the transit time of recharge water in the unsaturated zone is defined as the time between when water enters the soil at the land surface and when it reaches the water table. Infiltration refers to the entry of precipitation or irrigation water into soil at the land surface. Recharge refers to the movement of water from the unsaturated zone into the saturated zone. "New" infiltration water refers to soil water that entered the soil during the most 


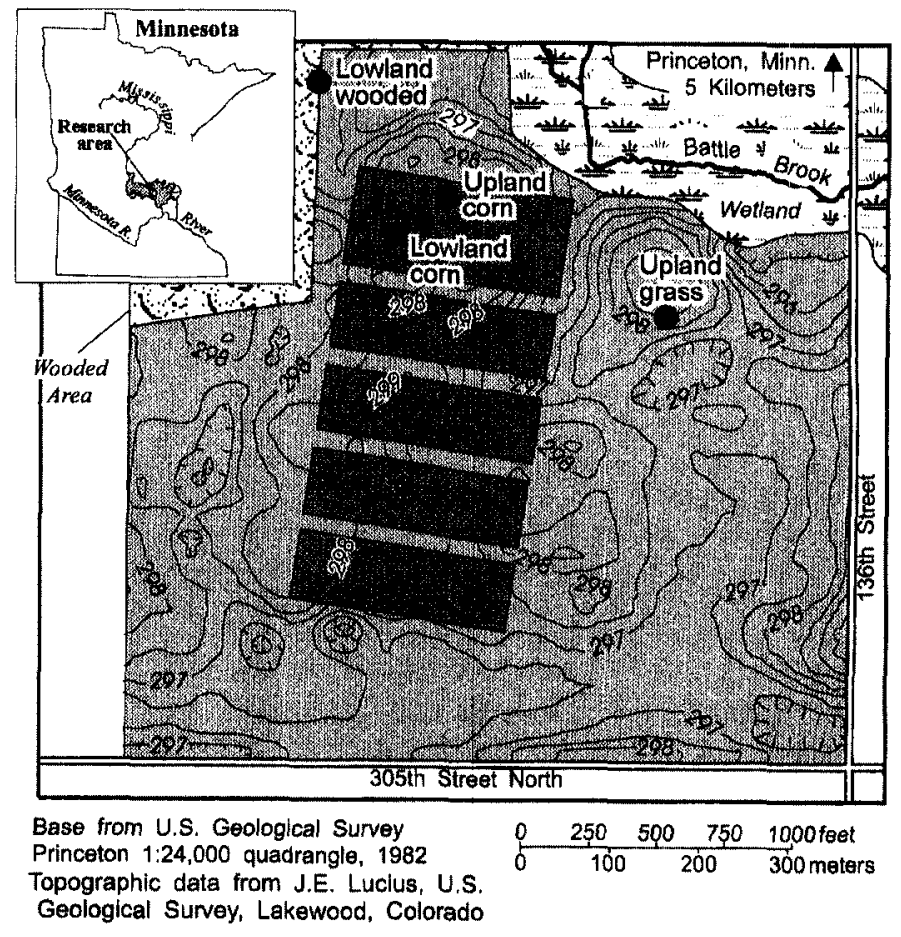

EXPLANATION

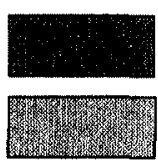

Cropped area

Research area, including cropped areas

\section{Lowland Site where samples were collected wooded from the water table, with site name

Upland
com

from the water table and unsaturated
zone, with site name

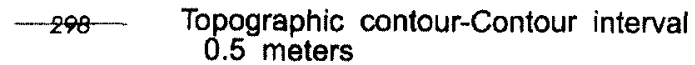

Figure 1. Location of sampling sites at the Princeton, Minnesota, Management Systems Evaluation Area, 1993-94.

recent precipitation or irrigation event. "Old" soil water refers to water that was in the soil prior to the most recent precipitation or irrigation event.

An important component of the study was the use of stable isotopes of oxygen $\left(\delta^{18} \mathrm{O}\right)$ and hydrogen $(\delta \mathrm{D})$ as conservative tracers of water sources and movements (International Atomic Energy Agency 1981; Payne 1988; Coplen 1993). Values of $\delta^{18} \mathrm{O}$ and $\delta \mathrm{D}$ in precipitation, soil water, and ground water have been used to identify the sources and pathways of recharge to unconfined aquifers (Gat and Tzur 1967; Zimmerman et al. 1967; Saxena 1984; Bengtsson et al. 1987; Barnes and Allison 1988; Darling and Bath 1988; Stewart and McDonnell 1991; Wenner et al. 1991; Lindstrom and Rodhe 1992; Mathieu and Bariac 1996; Burns et al. 1998). In this study, $\delta^{18} \mathrm{O}$ and $\delta \mathrm{D}$ values in rain, snow, irrigation water, soil water, and ground water were used with soil-moisture contents and water levels to estimate transit times and pathways of recharge water in the unsaturated zone. Tracking water movement through the unsaturated zone with soil-moisture measurements alone does not reveal transit time because recharge can be composed of (1) stored water in the unsaturated zone that is displaced by new infiltration (piston flow), or (2) new infiltration that moves rapidly through the unsaturated zone along preferential flowpaths. However, recharge waters moving by these different pathways may be distinguished on the basis of their stable isotope values (Gat and Tzur 1967). The approximate time (or season) that water infiltrated into the unsaturated zone was estimated by comparing its isotopic composition with that of precipitation and irrigation water. The transit time of recharge water in the unsaturated zone was estimated from the difference in time between when water with a distinctive isotopic composition infiltrated at land surface and when it was detected at the water table.

\section{Site Description}

The study was conducted at the Management Systems Evaluation Area (MSEA) near Princeton, Minnesota (Figure 1). The Princeton MSEA is within the Anoka Sand Plain, an area of glacial outwash covering about $4400 \mathrm{~km}^{2}$ (Figure 1; Delin et al. 1994). The topography is gently undulating at the 65 -hectare research area. The topsoil is principally a mixed, frigid Argic Udipsamment (Jackson 1991). The soil is well drained and there is surface ponding only when the soil is frozen or when more than about $50 \mathrm{~mm}$ of water is applied in a 24-hour period. The unsaturated zone consists predominantly of fine to medium-grained sand, and the saturated zone of medium to coarse-grained sand (Delin et al. 1994). The porosity is generally $35 \%$ to $40 \%$. Field capacity in the upper 0.5 $\mathrm{m}$ of the unsaturated zone is typically $10 \%$ to $12 \%$ by volume (vol\%) (Komor and Emerson 1994). The average depth to the water table is $3.6 \mathrm{~m}$ below land surface across the research area. Ground water moves from west to east at an average rate of $80 \mathrm{~mm} / \mathrm{d}$ (Delin et al. 1994). Ground water recharge generally ranges from about 50 to $250 \mathrm{~mm}$ per year and occurs primarily during March through July (Delin et al., in press). Most of the approximately 778 mm of mean annual precipitation (U.S. Department of Commerce 1961-92) is rainfall during May through September. Natural precipitation totals were 770 and $660 \mathrm{~mm}$ for 1993 and 1994, respectively (Delin et al. 1997). Mean potential evapotranspiration calculated by the Thornthwaite method is $610 \mathrm{~mm}$ per year (Baker et al. 1979). Mean monthly temperatures vary from $21^{\circ} \mathrm{C}$ in July to $-14^{\circ} \mathrm{C}$ in January (Baker et al. 1985).

\section{Methods}

\section{Sample Collection and Analysis}

Rain water and irrigation water applied with a linear-move spray irrigation system was collected at the upland corn site (Figure 1) using a funnel mounted on a pole $1.5 \mathrm{~m}$ above land surface, connected to a buried $20 \mathrm{~L}$ bottle. Samples were collected at least monthly and two to four times per month during selected periods, including some samples of individual rainstorms. Irrigation samples were collected following selected applications. The water collected was a composite sample of bulk precipitation or irrigation since the last sample collection. Snow samples were collected by filling a $1 \mathrm{~L}$ glass jar with a depth-integrated sample of the snowpack. Monthly and annual average, volume-weighted isotopic values of precipitation were calculated from isotopic values of all precipitation samples and measured precipitation amounts occurring during each sampling period using a formula of Yurtsever and Gat (1981).

Irrigation was applied as necessary to supplement rainfall on cropped areas. The irrigation well was completed in a confined sand 
and gravel aquifer that is hydraulically separated from the surficial aquifer by a confining layer of clayey till about $15 \mathrm{~m}$ thick (Delin et al. 1994).

Four water table wells were sampled in this study. Two of the wells were located in the northernmost cropped area, which was planted with field corn in consecutive years under conventional fullwidth tillage and split nitrogen applications (multiple small applications of nitrogen during the growing season rather than one large application) (Landon et al. 1998). One well was within a topographically high area (upland corn) and the other in a topographically low area (lowland corn) about $78 \mathrm{~m}$ apart that differed in elevation by $1.4 \mathrm{~m}$ (slope of about 0.02) (Figure 1). Between 20 and $65 \mathrm{~mm}$ of irrigation water were applied to the corn at various times in the growing season to supplement rainfall (Figure 2a) (Landon et al. 1997). Controlled infiltration experiments during which 120 to $240 \mathrm{~mm}$ of irrigation water were applied were also conducted at the upland and lowland corn sites on September 15 and October 19, 1993, and August 31, 1994 (Delin et al. 1997). The third well was in an upland area planted in grass (upland grass) (Figure 1). This area was farmed prior to 1991 but was planted with a mixture of timothy and smooth brome grass during this study. The fourth well was located on the eastern, or downgradient, end of a wooded area (lowland wooded) with mixed hardwoods (Figure 1).

Ground water samples were collected monthly, coincident with precipitation samples, and following selected recharge events. The wells were constructed of $51 \mathrm{~mm}$ I.D. galvanized steel or polyvinyl chloride (PVC) casing with 0.6 or $1.5 \mathrm{~m}$ long stainlesssteel screens bisecting the water table (screen depths for specific wells are listed in Figures $2 f$ and $3 f$ ). Ground water was sampled with a peristaltic pump at a rate of 0.5 to $1.0 \mathrm{~L} / \mathrm{min}$ with the inlet hose to the pump held 50 to $100 \mathrm{~mm}$ below the water table. Water samples were collected after the specific conductance, $\mathrm{pH}$, and dissolved oxygen concentrations stabilized. A $60 \mathrm{~mL}$ glass bottle with a gas-excluding polyseal cap was filled for analysis of $\delta^{18} \mathrm{O}$ and $\delta \mathrm{D}$ values. One 15 or $125 \mathrm{~mL}$ opaque polyethylene bottle was filled with water passed through a $0.45 \mu \mathrm{m}$ cellulose-nitrate filter and chilled for anion analyses.

Soil water was collected from suction lysimeters and wick samplers in the unsaturated zone at the upland and lowland corn sites at the same time samples were collected from the water table (depths for specific samplers are listed in Figures $2 c, 2 d, 2 e, 3 c, 3 d$, and $3 \mathrm{e}$ ). Laboratory tests indicated that no isotopic fractionation occurred a result of collection with either type of sampler (Landon et al. 1999). The suction lysimeters were constructed of Teflon ${ }^{\circledR}$ with a porous ceramic cup. Soil water was collected by applying a vacuum of about 35 centibars to the lysimeters for at least one hour. The suction lysimeters yielded $10 \mathrm{~mL}$ to $2 \mathrm{~L}$ of water with an average of about $50 \mathrm{~mL}$. Wick samplers were based on the design of Brown et al. (1986). Samples collected with the wick samplers represented a composite of predominantly gravity-drainage water over the time since the sampler was last emptied (Landon et al. 1999).

Values of $\delta^{18} \mathrm{O}$ and $\delta \mathrm{D}$ were determined by mass spectrometry at the U.S. Geological Survey (USGS) Stable Isotope Fractionation Laboratory in Reston, Virginia. The analytical precisions of the $\delta^{18} \mathrm{O}$ and $\delta \mathrm{D}$ results were 0.15 and $1.5 \%$, respectively (Mullin 1995). Isotopic results were reported in \%o relative to Vienna Standard Mean Ocean Water (VSMOW). Water samples were analyzed for dissolved nitrate using ion chromatography at the University of Minnesota, Department of Geology and Geophysics, or at the USGS, Denver, Colorado. The data and descriptions of the sample collection, analysis, and quality assurance protocols are in Landon et al. (1997) and Delin et al. (1997).

\section{Water Movement}

Thermocouples for measuring soil temperatures and timedomain reflectometry (TDR) probes for measuring volumetric soil-moisture contents (Topp et al. 1980) were installed in two vertical profiles at both the upland and lowland corn sites at depths of $0.2,0.4,0.6,0.8,1.0,1.5,2.0,2.5$, and $3.0 \mathrm{~m}$. The instrumentation was installed during October-November 1991 in trench walls (Delin and Landon 1996; Delin et al. 1996). Soil temperature, soil-moisture contents, ground water levels, and precipitation were recorded at hourly to daily intervals at both sites.

\section{Results}

\section{Isotopic Values of Precipitation and Irrigation}

There was a large seasonal variation in the isotopic composition of precipitation (Figure $2 b$ ). Samples of irrigation water were collected three times and had $\delta^{18} \mathrm{O}$ values of -9.3 to $-9.4 \%$. Because $\delta^{18} \mathrm{O}$ values of irrigation water were uniform, Figure $2 \mathrm{~b}$ shows an isotopic data point for every irrigation water application, although samples were not collected after every application. Precipitation and irrigation were classified into three seasonal categories defined by isotopically distinct compositions (Table 1). The result of the seasonal contrast in isotopic composition was that water available for infiltration into the soil during March-April (hereafter referred to as spring) and October-November (hereafter referred to as fall) was generally $<-12 \%$, isotopically distinct from infiltration during May-September (hereafter referred to as summer), generally $>-10 \%$.

\section{Wetting-Front Movement}

Soil-moisture data indicated that it took wetting fronts hours to weeks to move through the unsaturated zone (Figures 2, 3, and 4 ; Delin et al., in press). Recharge occurred following most rainstorms or irrigation applications of greater than about $15 \mathrm{~mm}$. For instance, following the application of $64 \mathrm{~mm}$ of irrigation water on July 14,1993 , the wetting fronts moved rapidly through the unsaturated zone and a small water table rise was detected about 24 hours later (Figure 4). Increased amounts of water application resulted in increased rates of wetting front movement and recharge (Delin et al., in press). The average rate of wetting front movement for

\begin{tabular}{|c|c|c|c|}
\hline \multicolumn{4}{|c|}{$\begin{array}{c}\text { Table } 1 \\
\text { Classification of Annual Precipitation and Irrigation into } \\
\text { Seasonal Categories Based on Isotopic Composition }\end{array}$} \\
\hline $\begin{array}{l}\text { Seasonal } \\
\text { Category }\end{array}$ & $\begin{array}{l}\text { Water } \\
\text { Source }\end{array}$ & $\delta^{18} \mathrm{O} \%$ & $\begin{array}{l}\text { Months Occurring } \\
\text { or Available for } \\
\text { Infiltration }\end{array}$ \\
\hline Spring & snow melt & $<-17$ & March \\
\hline Spring & rainfall & -12 to -14 & March-April \\
\hline Summer & $\begin{array}{l}\text { rainfall and } \\
\text { irrigation }\end{array}$ & .5 to -10 & May-September \\
\hline Fall & rainfall & -12 to -14 & October-November \\
\hline Fall & snow melt & $<-17$ & November \\
\hline
\end{tabular}



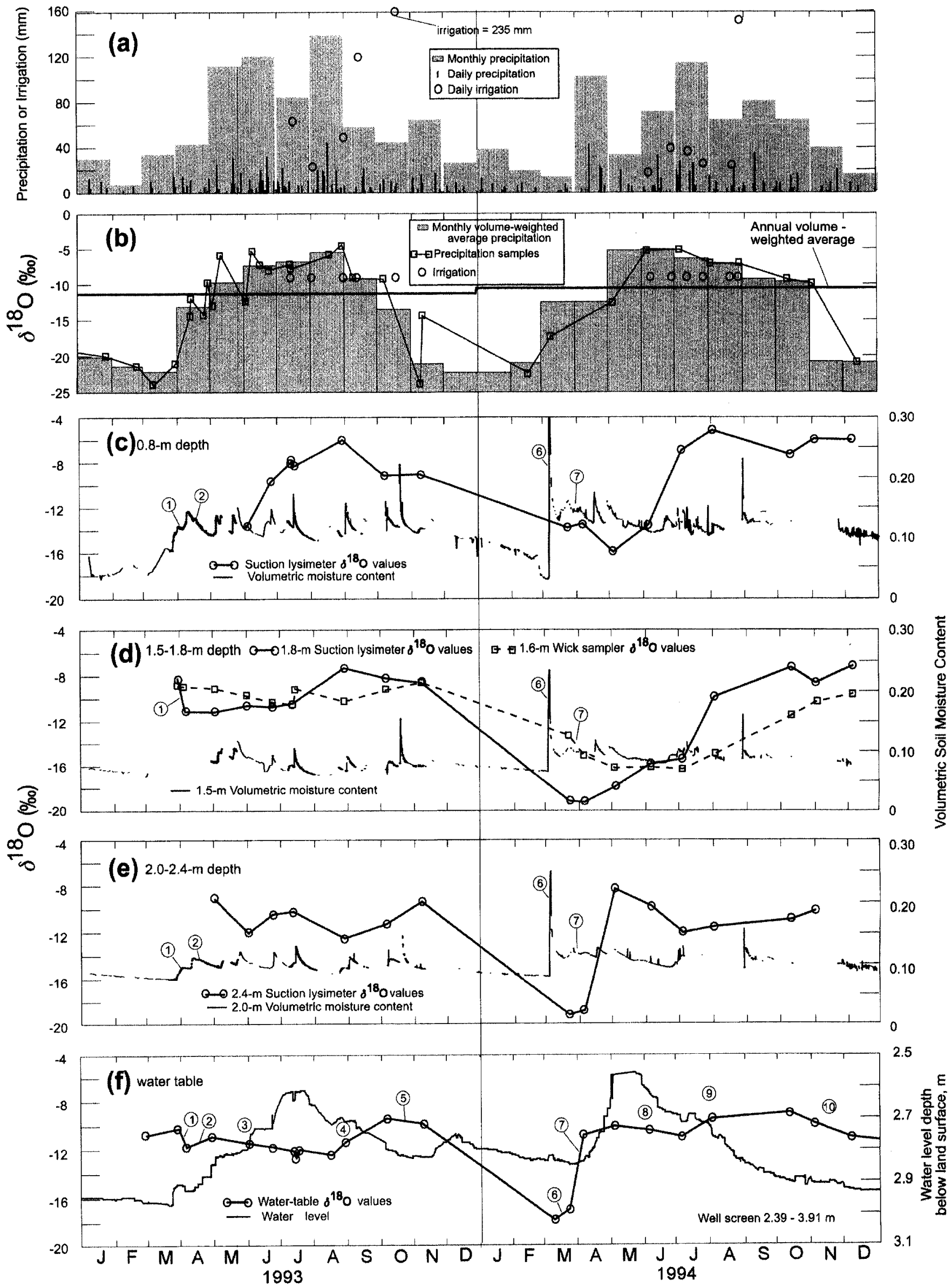

Figure 2. Lowland corn site precipitation, irrigation, volumetric soil-moisture content, and water level data plus $\delta^{18} \mathrm{O}$ values for precipitation, irrigation water, soil water, and ground water from the water table, 1993-94. Circled numbers indicate the occurrence of numbered events shown in Table 4 and discussed in the text. 

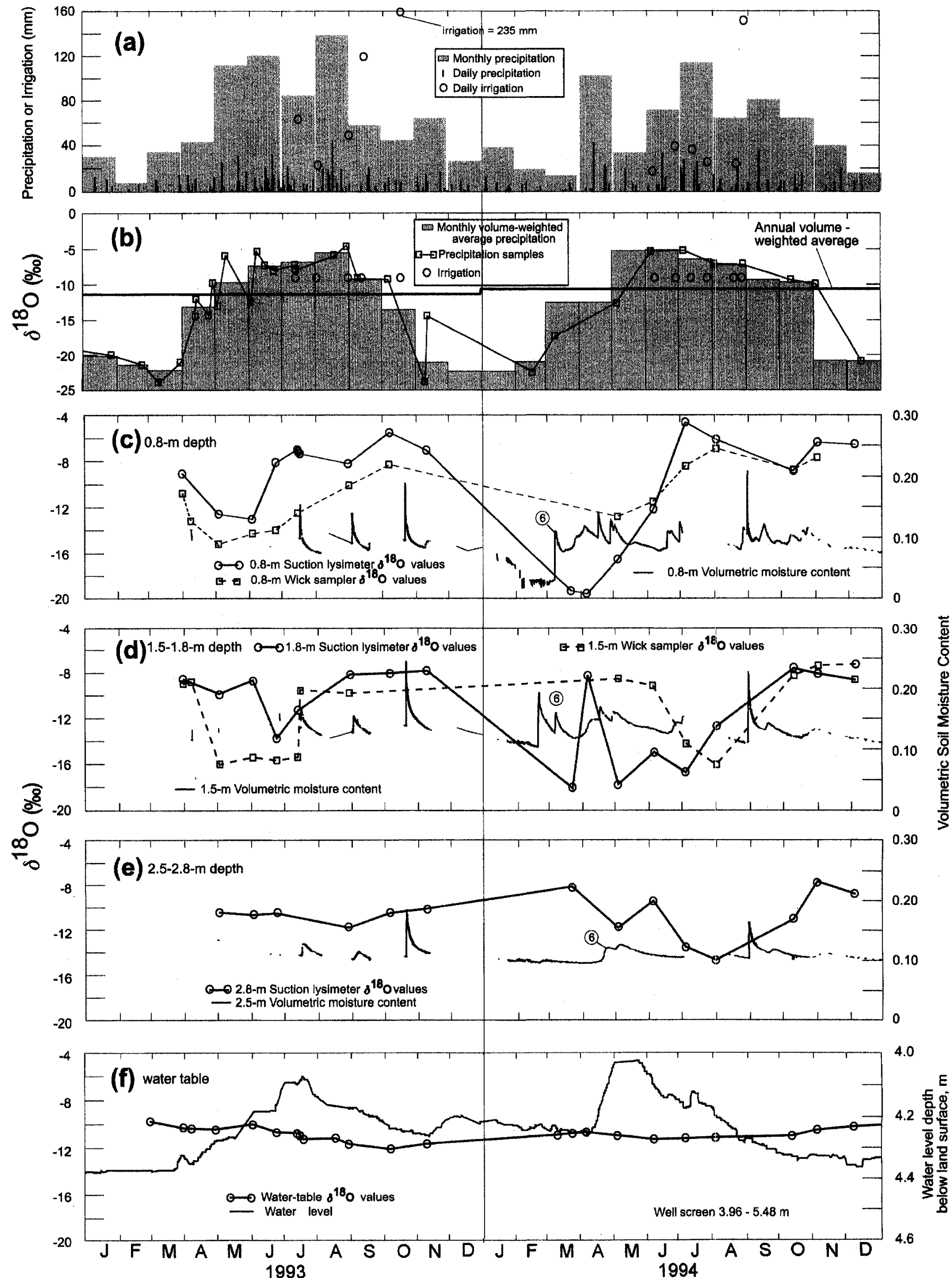

Figure 3. Upland corn site precipitation, irrigation, volumetric soil-moisture content, and water level data plus $\delta^{18} \mathrm{O}$ values for precipitation, irrigation water, soil water, and ground water from the water table, 1993-94. 

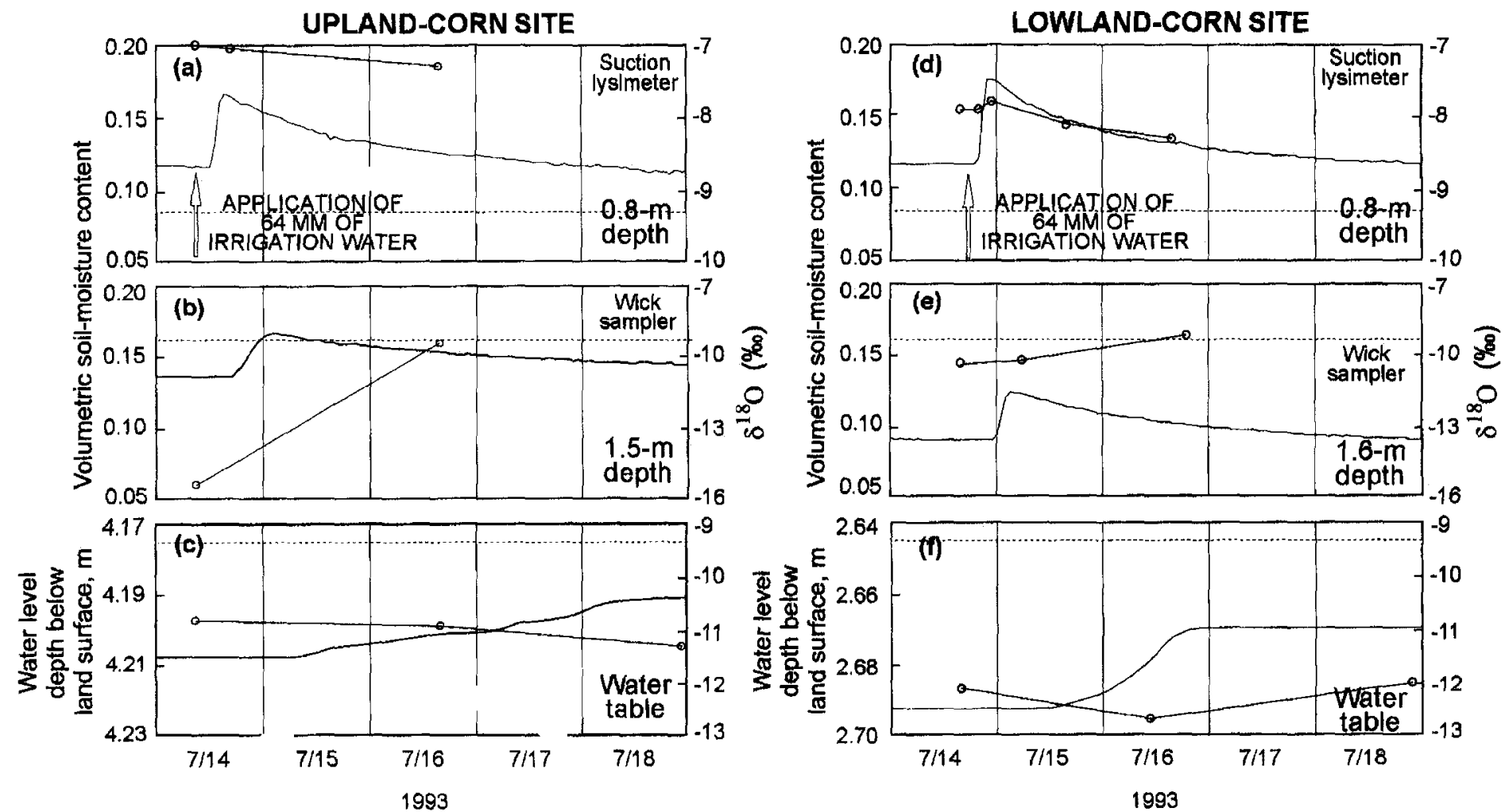

\section{EXPLANATION}

$\multimap \delta^{18} \mathrm{O}$ Values of soil water or ground water

............. $\delta^{18} \mathrm{O}$ values of irrigation water

- Soil-moisture content or water level

Figure 4. Irrigation, volumetric soil-moisture content, and water level data plus $\delta^{18} \mathrm{O}$ values for irrigation water, soil water, and ground water from the water table following application of irrigation water on July 14, 1993, at the upland corn site (a-c) and the lowland corn site (d-f).

recharge events was about $15 \mathrm{~mm} / \mathrm{hr}$, which resulted in an average wetting front travel time through the unsaturated zone of eight days at the lowland corn site and 12 days at the upland corn site. Water applications smaller than about $15 \mathrm{~mm}$ had little effect on soilmoisture contents below the $1.0 \mathrm{~m}$ depth. Soil-moisture contents were not measured continuously during the study because of intermittent instrument failure and because system components were shared between the lowland and upland sites in 1993. Soil-moisture contents recorded during winter at depths shallower than $1.0 \mathrm{~m}$ were inaccurate owing to frozen soil conditions.

Wetting fronts typically moved through the unsaturated zone and recharged the aquifer more rapidly at the lowland corn site than at the upland corn site (Delin et al. in press). The largest differences in wetting-front movement between the two sites occurred in March-April 1994 during snow melt. The most rapid movement of a wetting front observed during the study occurred in early March 1994 at the lowland corn site during snow melt (event 6, Figures 2c, $2 \mathrm{~d}$, and $2 \mathrm{e}$ ). The wetting front moved from the $0.2 \mathrm{~m}$ TDR probe to the $2.5 \mathrm{~m}$ TDR probe above the water table in four hours. Soilmoisture contents increased from 0.08 prior to infiltration to 0.25 at a depth of $2.0 \mathrm{~m}$ below land surface, indicating the sandy soil approached $60 \%$ to $70 \%$ saturation (event 6 , Figure $2 \mathrm{e}$ ). In contrast to this rapid wetting-front movement, the wetting front at the upland corn site was not observed at the $2.0 \mathrm{~m}$ TDR probes until April, approximately six weeks later, and the increase in moisture content was much less than at the lowland corn site, with a peak value of 0.12 reached at the $2.0 \mathrm{~m}$ probe (event 6 , Figure $3 \mathrm{e}$ ).

\section{Isotopic Values of Soil Water}

Values of $\delta^{18} \mathrm{O}$ and $\delta \mathrm{D}$ for soil water plotted mainly on, or slightly to the right of, the local meteoric water line (LMWL), indicating that soil water was predominantly meteoric but had a slight evaporative component (Figure 5). Soil water samples generally were less than $1 \%$ o to the right of the LMWL, indicating that the magnitude of evaporative modification of soil water $\delta^{18} \mathrm{O}$ was small in comparison to seasonal variations in isotopic compositions (Figure 5).

The isotopic composition of soil water changed seasonally (Figures $2 \mathrm{c}, 2 \mathrm{~d}, 2 \mathrm{e}, 3 \mathrm{c}, 3 \mathrm{~d}$, and $3 \mathrm{e}$ ). Soil water $\delta^{18} \mathrm{O}$ values decreased following snow melt and April rainfall and increased following summer rainfall and irrigation. Seasonal changes in soil-water isotopic composition often lagged behind changes in precipitation. For instance, at the upland corn site in 1993, the annual minimum isotopic values of soil water $(-12$ to $-17 \%$ ) at all sample depths occurred during the summer months (Figures 3c, 3d, and $3 \mathrm{e}$ ). These minimum isotopic values indicated the presence of ${ }^{18} \mathrm{O}$ depleted water that infiltrated during March and April.

Although the seasonal variations in soil water $\delta^{18} \mathrm{O}$ values were clearly large enough to be measured and tracked through the unsaturated zone, the range of $\delta^{18} \mathrm{O}$ values in soil water was less than the seasonal fluctuation in precipitation $\delta^{18} \mathrm{O}$ values. This dampening of soil water $\delta^{18} \mathrm{O}$ variations compared to those of precipitation indicates that mixing of waters with different isotopic compositions occurred in the soil.

To evaluate the extent of the mixing of soil water, measured soil- 


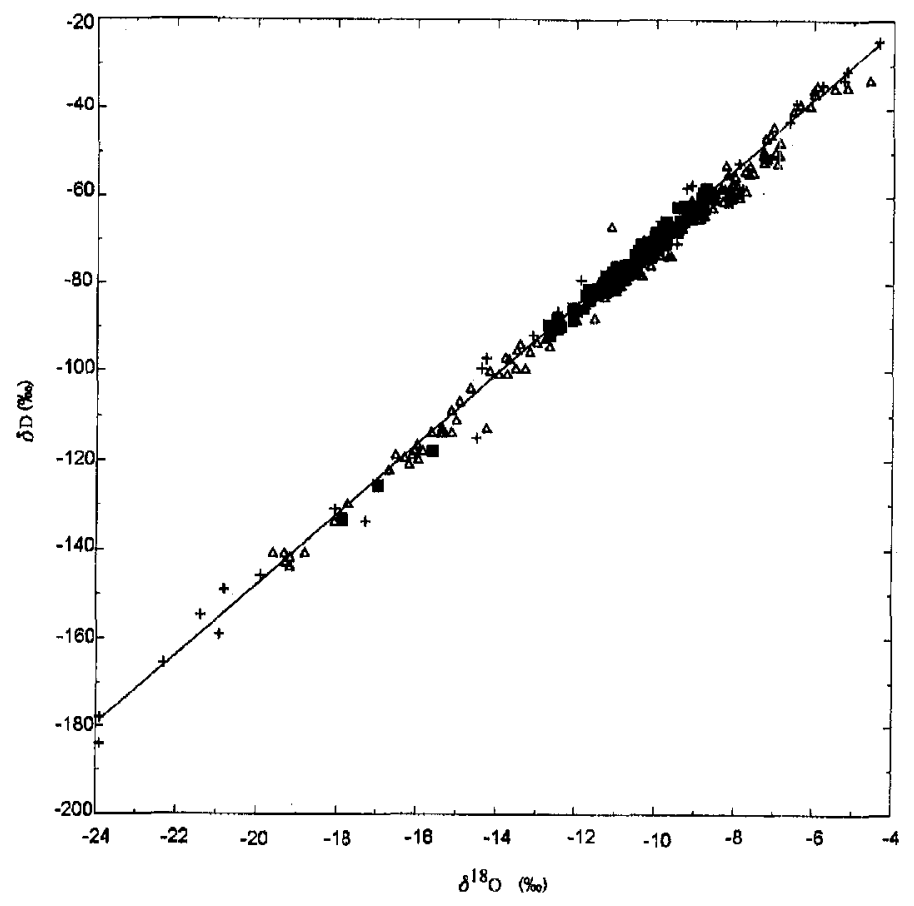

EXPLANATION

\section{- Local meteoric water line \\ + Precipitation \\ $\triangle$ Soll water from suction lysimeters and wick samplers \\ - Ground water}

Figure 5. $\delta^{18} \mathrm{O}$ and $\delta \mathrm{D}$ values for precipitation, soil water collected from suction lysimeters and wick samplers, and ground water from the water table during 1993-94. The isotopic values of 33 precipitation samples defined a local meteoric water line of $\delta D=7.9 \delta^{18} \mathrm{O}+9.4$ $\left(\mathbf{r}^{2}=0.99\right)$.

water isotopic values were compared with simulated values from (1) a pure-piston flow model simulating no mixing of new infiltration water with older soil water (hereafter referred to as the pure-piston flow model), and (2) a compartmental model simulating complete mixing of new infiltration water with older soil water in $0.5 \mathrm{~m}$ cells and piston flow between the cells (hereafter referred to as the mixing-cell model). Water and isotopic mass balances were calculated with these simple models. Water balance calculations were performed for all 27 infiltration events during 1993-94 that caused measureable increases in soil-moisture contents below $0.5 \mathrm{~m}$. The amount of infiltration for each event was calculated by subtracting the total amount of soil water in the unsaturated zone prior to the event from the maximum amount of soil water during the infiltration event. Losses of soil water to evapotranspiration were estimated by means of a crop-growth model (Reicosky et al. 1995) and loss of soil water to recharge was calculated as a residual. For the pure-piston flow model, the amount of water that infiltrated during each event was used to calculate the thickness of the unsaturated zone occupied by water from that event based on measured soil-moisture contents. The thickness and vertical location of water from each event was then calculated as that water moved downward through the unsaturated zone as a result of displacement by subsequent infiltration events. Soil water isotopic values were equal to the original isotopic values of the water when it infiltrated. For the mixing-cell model, the unsaturated zone was divided into a one-dimensional intercon- nected array of mixing cells (a compartmental model after Yurtsever [1983]), each cell simulating a $0.5 \mathrm{~m}$ vertical interval. A water balance was calculated for each mixing cell based on changes in measured soil-moisture contents. The isotopic composition in each mixing cell was computed using the isotopic mixing equation (Gat 1981). Since complete mixing occurred in each cell, the water moving out of the bottom of each mixing cell due to downward percolation was assumed to have the same composition as the water in the mixing cell. The isotopic value of the water leaving the mixing cell defined that of the water entering the mixing cell below. The mixing-cell model, involving piston flow between cells and mixing within cells, is a hydrid model between pure piston and pure mixing conditions. A pure-mixing model of only one cell representing the entire unsaturated zone was considered unrealistic, since measured soil-water isotopic values were not vertically uniform. The mixing-cell model was meant to simulate a condition of locally complete or "pure" mixing and vertical transport of that mixed water.

Comparison of measured isotopic values with those from the pure-piston flow and mixing-cell models indicates that soil water was usually highly mixed (Figure 6). For most samplers and times, soil water $\delta^{18} \mathrm{O}$ values were similar to those predicted by the mixing-cell model; measured values generally did not compare as closely to values predicted by the pure-piston flow model. However, some seasonal oscillations in soil water $\delta^{18} \mathrm{O}$ values were slightly larger than those predicted by the mixing-cell model, indicating that soil waters were not completely mixed.

\section{Ground Water Isotopic Values and Nitrate Concentrations}

The isotopic composition of ground water just below the water table varied among the four sites (Table 2). All ground water samples plotted on the LMWL, indicating that ground water was meteoric water unmodified by post- or syninfiltration fractionation due to evaporation (Figure 5).

Isotopic values at the water table changed cyclically each year at each site (Figures $2 \mathrm{f}$ and $3 \mathrm{f}$ ). The magnitude of the ground water isotopic changes reflect an isotopic mass balance that depends on the composition of the recharge, the amount of recharge, the depth of water in the screen (height of water table), and the initial composition of the ground water in the screen prior to recharge. However, the principle factor driving changes in the isotopic values of ground

Table 2

Average, Minimum, and Maximum $\delta^{18} O$ Values for Ground Water from the Water Table and Precipitation Collected During 1993-94

\begin{tabular}{|c|c|c|c|c|}
\hline Site & $\begin{array}{c}\text { Average } \\
\delta^{18} \mathrm{O} \\
\text { Value }(\% \circ)\end{array}$ & $\begin{array}{c}\text { Minimum } \\
\delta^{18} \mathrm{O} \\
\text { Value (\%o) }\end{array}$ & $\begin{array}{c}\text { Maximum } \\
\delta^{18} \mathrm{O} \\
\text { Value }(\% \circ)\end{array}$ & $\begin{array}{c}\text { Number } \\
\text { of } \\
\text { Samples }\end{array}$ \\
\hline \multicolumn{5}{|l|}{ Ground Water } \\
\hline Lowland corn & -11.4 & -17.9 & -8.9 & 23 \\
\hline Upland corn & -10.9 & -12.1 & -9.8 & 23 \\
\hline Lowland wooded & -10.4 & -12.7 & -9.2 & 16 \\
\hline Upland grass & -9.7 & -11.1 & -8.7 & 16 \\
\hline All sites above & -10.7 & -17.9 & -8.7 & 78 \\
\hline \multicolumn{5}{|l|}{ Precipitation } \\
\hline 1993 & $-11.2^{1}$ & -23.9 & -4.4 & 23 \\
\hline 1994 & $-10.6^{1}$ & -22.3 & -5.1 & 10 \\
\hline
\end{tabular}


UPLAND-CORN SITE

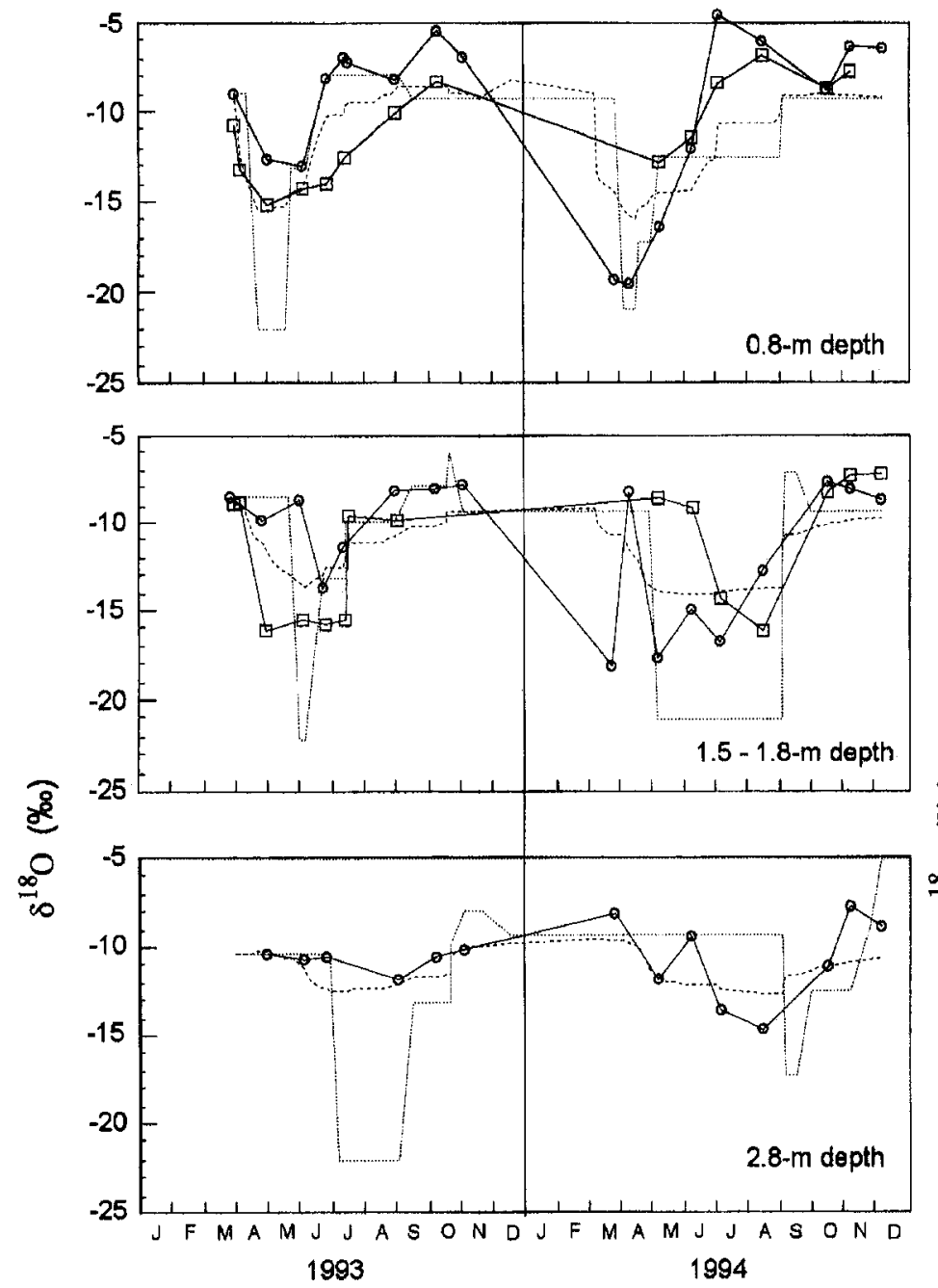

LOWLAND-CORN SITE
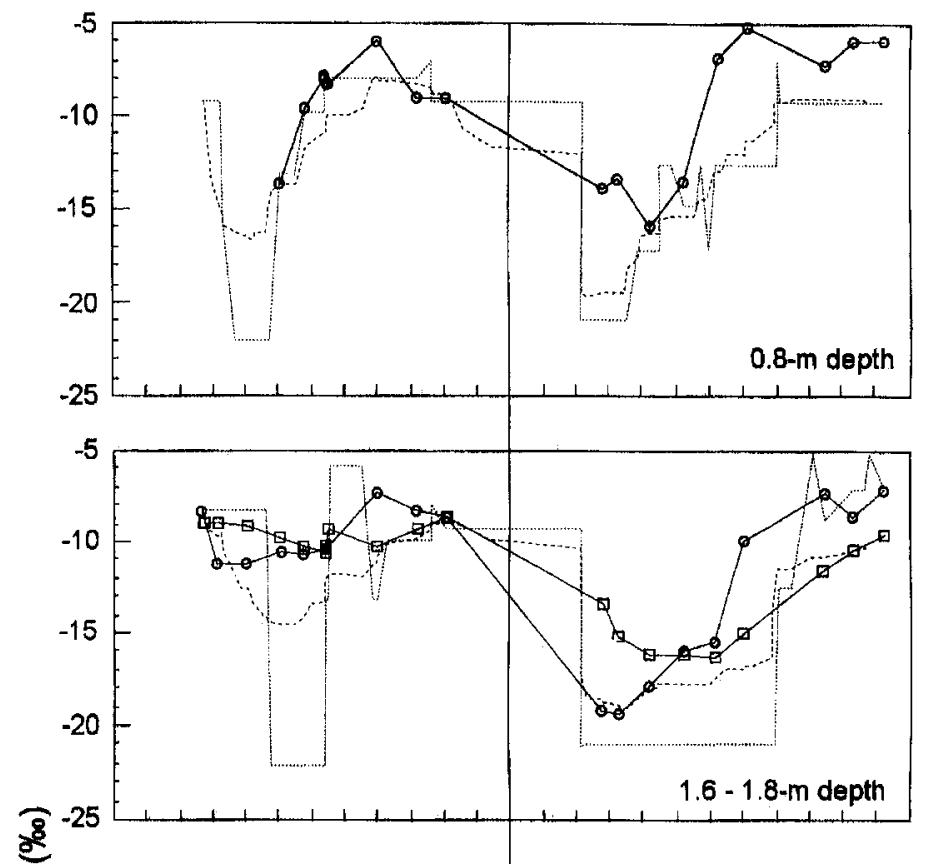

${ }_{\infty}^{\infty}$

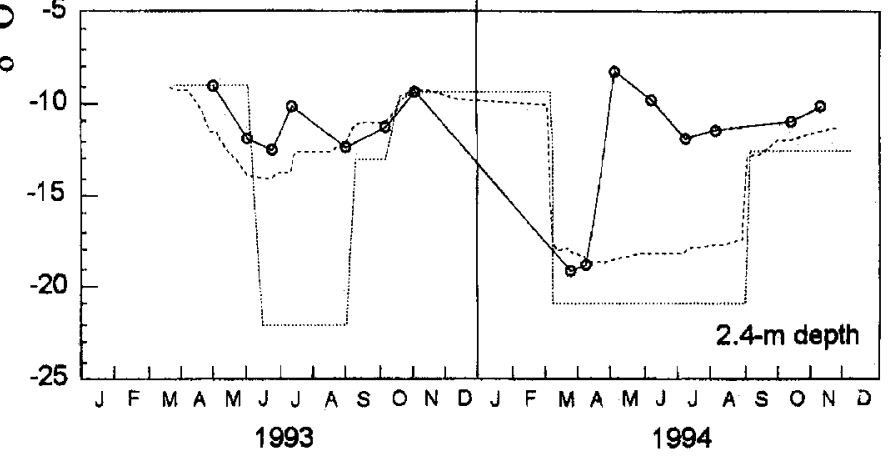

EXPLANATION

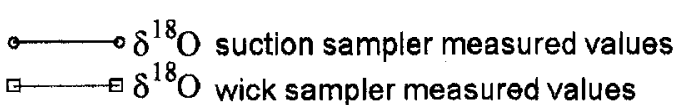

$\delta^{18} \mathrm{O}$ simulated values - mixing-cell model $\delta^{18} \mathrm{O}$ simulated values - piston-flow model

Figure 6. Comparison of measured $\delta^{18} \mathrm{O}$ values of soil water to simulated values using pure-piston flow and mixing cell models for the upland and lowland corn sites, 1993-94.

water was changes in the isotopic value of recharge. Therefore, the direction and timing of changes in isotopic values in ground water were an indicator of the composition and timing of recharge.

The isotopic contrast between ground water and seasonal precipitation (or irrigation) made it possible to identify the season during which recharge water infiltrated. Because the $\delta^{18} \mathrm{O}$ values of winter precipitation $(<-17 \%)$, spring rain $(<-12 \%)$, and late fall precipitation $(<-12 \%$ ) were less than ground water values prior to recharge of these waters (Tables 1 and 2; Figure 7), those sources of recharge caused the $\delta^{18} \mathrm{O}$ values of ground water at the water table to decrease. Because the $\delta^{18} \mathrm{O}$ values of summer precipitation and irrigation water $(\geq 10 \%$ o) were larger than ground water values prior to recharge of these waters (Tables 1 and 2; Figure 7), those sources of recharge caused the $\delta^{18} \mathrm{O}$ values of ground water at the water table to increase. The shading in Figure 7 shows periods when recharge water had an isotopic composition that indicated the water was derived from spring (March-April), summer (May-September), or fall (October-November) infiltration. The beginning of the spring infiltration period was assumed to coincide with snow melt and thawing of the soil. Soil-moisture data indicated that little or no infil- tration occurred during the winter when the soil was frozen (Figures 2 and 3 ).

The apparent transit time is indicated by the offset of the shading between the infiltration (source) water and the ground water at a particular site (Figure 7). Because infiltration of water with a particular seasonal composition can occur over a period of weeks to months, minimum and maximum estimates of the transit time were calculated by comparing first occurrence of seasonal isotopic signals in precipitation to first and last occurrence of that signal at the water table (Table 3). Because recharge of water having a particular composition could have occurred any time during the month between successive sample collections, there was an uncertainty of \pm 0.5 month in transit time estimates unless otherwise noted.

\section{Isotopic Values and Nitrate Concentrations at the Lowland Corn Site}

Changes in the isotopic values of ground water at the water table followed an annual sequence that resulted from seasonal changes in the composition of recharge. Isotopic changes at the lowland corn 

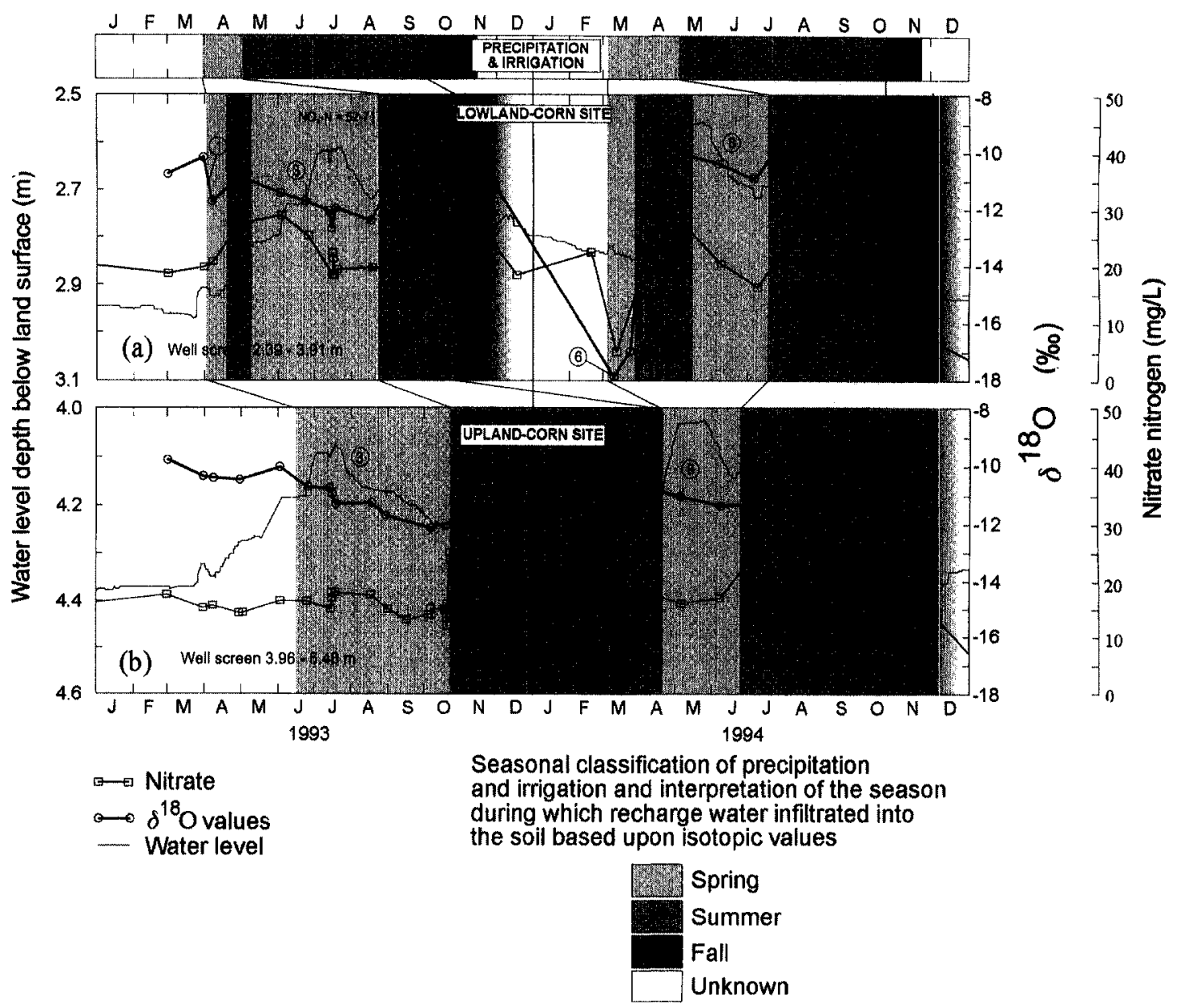

Figure 7. Water levels, $\delta^{18} \mathrm{O}$ values, and nitrate-nitrogen concentrations at the water table during 1993-94 at the (a) lowland corn and (b) upland corn sites. The shading at the top of the figure shows the seasonal classification of precipitation plus irrigation water, based on $\delta^{18} \mathrm{O}$ values, into spring, summer, and fall categories. The shading below indicates the season association of recharge water based on the $\delta^{18} \mathrm{O}$ of ground water. Circled numbers indicate the occurrence of numbered events shown in Table 4 and discussed in the text.

Table 3

Minimum and Maximum Transit Times in the Unsaturated Zone for Water Recharged During 1993-94, Based on Changes in Ground Water $\delta^{18} \mathrm{O}$ Values

\begin{tabular}{|c|c|c|c|c|}
\hline & $\begin{array}{l}\text { Lowland } \\
\text { Corn }\end{array}$ & $\begin{array}{l}\text { Upland } \\
\text { Corn }\end{array}$ & $\begin{array}{l}\text { Lowland } \\
\text { Woodland }\end{array}$ & $\begin{array}{l}\text { Upland } \\
\text { Grassland }\end{array}$ \\
\hline \multicolumn{5}{|l|}{ Spring 1993} \\
\hline Minimum & $<$ l week & 2.5 months & $<3$ weeks & 3 months \\
\hline Maximum & 4-5 months 1 & $6-7$ months & 3-4. months & $6-11$ months \\
\hline \multicolumn{5}{|l|}{ Summer 1993} \\
\hline Minimum & 3.5 months & 6 months & 3 months & - \\
\hline Maximum & $7-12$ months & $6.5-11.5$ months & $7 \sim 12$ months 1 & $7-12$ months $^{2}$ \\
\hline \multicolumn{5}{|l|}{ Fall 1993} \\
\hline Minimum & $<1$ month & ND & ND & $\mathrm{ND}$ \\
\hline Maximum & - & ND & ND & ND \\
\hline \multicolumn{5}{|l|}{ Spring 1994} \\
\hline Minimum & $<5$ days & 1.5 months & 2 months & 2 months \\
\hline Maximum & $2.5-4.5$ months & $1.5-3.5$ months & 2-4 months & 4-6 months ${ }^{2}$ \\
\hline \multicolumn{5}{|c|}{ Summer 1994} \\
\hline Minimum & 2.5 months & 1.5 months & 2 months & 4 months \\
\hline Maximum & $6-12$ months & $>7$ months & $2-6$ months & - \\
\hline \multicolumn{5}{|l|}{ Fall 1994} \\
\hline Minimum & $<1$ month & $\mathrm{ND}$ & $<1$ month & ND \\
\hline Maximum & - & $\mathrm{ND}$ & - & ND \\
\hline \multicolumn{5}{|c|}{$\begin{array}{l}\text { - Insufficient data for transit time to be calculated; ND, no detection of recharge of } \\
\text { water with that seasonal composition. } \\
{ }^{1} \text { Transit times with units of months have an uncertainty } \pm 0.5 \text { month unless otherwise } \\
\text { noted. } \\
{ }^{2} \text { Transit time uncertainty } \pm 1 \text { month. }\end{array}$} \\
\hline
\end{tabular}

site indicated the most frequent changes in recharge composition (Table 4; Figure 7a). Nitrate concentrations at the water table at the lowland corn site were closely linked to seasonal recharge. Although the magnitude and timing of the isotopic changes in 1993 and 1994 were slightly different, the seasonal trends were the same (Figure 7a); events 1, 2, 3, 4, and 5 in 1993 correspond to the same seasonal trends in recharge compositions as events 6, 7,8,9, and 10, respectively, in 1994 (Table 4).

Following snow melt and soil thawing in March-April 1993 and 1994, ground water $\delta^{18} \mathrm{O}$ values decreased (events 1 and 6; Table 4, Figure 7a). Other evidence for movement of snow melt water included: (1) wetting front movement through the unsaturated zone (event 1, Figures $2 \mathrm{c}$ and $2 \mathrm{e}$; event 6 , Figures $2 \mathrm{c}, 2 \mathrm{~d}$, and $2 \mathrm{e}$ ); (2) a rise in water levels (event 1, Figure 7a); and (3) decreased $\delta^{18} \mathrm{O}$ values in soil water (event 1 , Figure 2 d; following event 6 , Figures $2 \mathrm{~d}$ and 2e). During 1993, these changes occurred between March 31 and April 7, indicating that recharge water from snow melt had a transit time of less than one week in the unsaturated zone. Recharge of snow melt water did not substantially affect nitrate concentrations during 1993 (event 1, Figure 7a). In 1994, a wetting front moved through the unsaturated zone in about four hours following soil thaw and snow melt on March 6 . The $\delta^{18} \mathrm{O}$ value of ground water collected on March 10 of $-17.3 \%$ was in the range of snow melt values (event 6, Figure 2f; Table 1). Nitrate concentrations dropped sharply from $22 \mathrm{mg} / \mathrm{L}$ on February 17 to $5.0 \mathrm{mg} / \mathrm{L}$ on March 


\begin{tabular}{|c|c|c|c|c|c|}
\hline \multicolumn{6}{|c|}{$\begin{array}{l}\text { Table } 4 \\
\text { Annual Sequence of Isotopic Changes at the Water Table at the Lowland Corn Site Resulting } \\
\text { from Changes in Recharge Composition and Corresponding Changes in Nitrate Concentrations }\end{array}$} \\
\hline \multirow{2}{*}{$\begin{array}{l}\text { Direction of } \\
\text { Isotopic Change }\end{array}$} & \multicolumn{2}{|c|}{ Event \# (Figure 7a) } & \multirow[b]{2}{*}{ Timing of Shift } & \multirow{2}{*}{$\begin{array}{c}\text { Interpreted Seasonal } \\
\text { Association of Recharge }\end{array}$} & \multirow{2}{*}{$\begin{array}{c}\text { Nitrate } \\
\text { Concentrations }\end{array}$} \\
\hline & 1993 & 1994 & & & \\
\hline Decrease & 1 & 6 & March-April & $\begin{array}{c}\text { Snow melt moving by } \\
\text { preferential flow }\end{array}$ & level or decrease \\
\hline Increase & 2 & 7 & April & $\begin{array}{c}\text { Summer infiltration from } \\
\text { previous year }\end{array}$ & increase \\
\hline Decrease & 3 & 8 & May-August & $\begin{array}{l}\text { Snow melt and } \\
\text { April rainfall }\end{array}$ & decrease \\
\hline Increase & 4 & 9 & August-October & Summer infiltraion & increase \\
\hline Decrease & 5 & 10 & November & Fall infiltration & decrease \\
\hline
\end{tabular}

10 (event 6, Figure 7a).

In April 1993 and 1994, ground water $\delta^{18} \mathrm{O}$ values increased to -10.9 and $-10.1 \%$, respectively (events 2 and 7 , Figure $7 \mathrm{a}$ ). Rising water levels (events 2 and 7, Figure 7a) and declining soilmoisture contents (event 2, Figure 2e; event 7, Figures $2 \mathrm{c}, 2 \mathrm{~d}$, and 2e) indicated that recharge continued to occur during these isotopic changes. The increase in the ground water $\delta^{18} \mathrm{O}$ values requires recharge of water with a $\delta^{18} \mathrm{O}$ value greater than about $-10 \%$. Ground water nitrate concentrations increased in April 1993 and 1994 (events 2 and 7, Figure 7a).

During May through July or August of both years, $\delta^{18} \mathrm{O}$ values at the water table generally decreased (events 3 and 8 , Figure $7 a)$. The change to lower $\delta^{18} \mathrm{O}$ values is consistent with recharge of water that infiltrated into the soil in late March and April (Table 1). Ground water nitrate concentrations predominantly decreased during recharge of spring infiltration (events 3 and 8, Figure 7a). Nitrogen fertilizers were applied at rates of $78 \mathrm{~kg} / \mathrm{ha}$ on June 4 and $67 \mathrm{~kg} /$ ha on July 15, 1993 but had little or no immediate effect on ground water nitrate concentrations because recharge was composed of spring infiltration water.

During July or August to October, $\delta^{18} \mathrm{O}$ values at the water table increased to the annual maximum of -9.4 to $-8.9 \%$ (events 4 and 9 , Figure 7a), consistent with recharge of summer rainfall and irrigation water (Table 1). The peak nitrate concentrations in October and November 1993 were related to infiltration and tracer tests conducted August 31 through October 20, 1993. Nitrogen was applied around the upland and lowland corn sites for a tracer test at a rate of $418 \mathrm{~kg} / \mathrm{ha}$ on August 31 . The peak nitrate concentrations occurred following a large application of irrigation water of approximately $235 \mathrm{~mm}$ on October 19, 1993 (Figure 2a). Thus, the increase in nitrate concentrations in the fall of 1993 did not reflect typical land use or water movement conditions and were disregarded with respect to interpreting the relation of seasonal recharge to nitrate concentrations. During 1994, nitrate concentrations increased from 16 to $32 \mathrm{mg} / \mathrm{L}$ between July 2 and August 31 in association with recharge of summer infiltration (event 9, Figure 7a). Nitrogen fertilizers were applied only during the summer infiltration period with applications of $78 \mathrm{~kg} / \mathrm{ha}$ on June 9 and $62 \mathrm{~kg} / \mathrm{ha}$ on June 28, in addition to the application on May 3. Because nitrate concentrations were below the detection limit of $0.05 \mathrm{mg} / \mathrm{L}$ in the irrigation water, it was not the source of the increased nitrate concentrations associated with recharge of summer infiltration.

Beginning in October or November of both years, the $\delta^{18} \mathrm{O}$ values at the water table decreased (events 5 and 10, Figure 7a), con- sistent with recharge of fall infiltration water with lower $\delta^{18} \mathrm{O}$ values (Table 1). In 1993, nitrate concentrations declined as the effects of the October 19 tracer test faded. In 1994, nitrate concentrations declined from 16 to $6 \mathrm{mg} / \mathrm{L}$ between October 12 and December 6 .

\section{Ground Water Isotopic Values and Nitrate Concentrations at the Upland Corn Site}

The sequence of annual isotopic changes was simpler at the upland corn site than at the lowland corn site (Figures $7 \mathrm{a}$ and $7 \mathrm{~b}$ ). Rapid recharge of spring snow melt during events 1 and 6 (Figure $7 \mathrm{a}$ ) were not detected at the upland corn (Figure 7b), lowland woodland, or upland grassland sites.

Nitrate concentrations at the upland corn site did not change as much in relation to recharge as at the lowland corn site. Nitrate concentrations at the upland corn site were 13 to $19 \mathrm{mg} / \mathrm{L}$ throughout most of 1993 and 1994. The increased concentrations of 24 to $35 \mathrm{mg} / \mathrm{L}$ in October-November 1993 were related to the infiltration experiments (Figure $7 \mathrm{~b}$ ). Increased nitrate concentrations of 22 to $25 \mathrm{mg} / \mathrm{L}$ also occurred at times during July-October 1994 in association with recharge of summer infiltration water.

\section{Irrigation Infiltration Test}

Wetting front movement and soil and ground water isotopic values were monitored following a $64 \mathrm{~mm}$ irrigation application at the upland and lowland corn sites on July 14, 1993. Irrigation water had an $\delta^{18} \mathrm{O}$ value of $-9.3 \%$, larger than preirrigation ground water $\delta^{18} \mathrm{O}$ values of -10.8 and $-12.1 \%$ at the upland and lowland corn sites, respectively (Figures $4 \mathrm{c}$ and $4 \mathrm{f}$ ). At the lowland corn site, the $\delta^{18} \mathrm{O}$ value of a water table sample collected on July 16 was $0.6 \%$ less than before irrigation (Figure 4f). The water table sample was collected after wetting fronts had passed the deepest TDR-probe in the unsaturated zone and after an approximately $20 \mathrm{~mm}$ rise in the water table, indicating recharge had occurred (Figures $4 d, 4 e$, and $4 \mathrm{f}$ ). Similarly, the $\delta^{18} \mathrm{O}$ value at the water table at the upland corn site decreased by $0.5 \%$ during a $20 \mathrm{~mm}$ water table rise in the four days following irrigation (Figure $4 \mathrm{c}$ ). The decreases in $\delta^{18} \mathrm{O}$ values at the water table indicate that recharge was not composed of irrigation water, because recharge of irrigation water would cause $\delta^{18} \mathrm{O}$ values to increase. Isotopic mass balance calculations indicate that the $\delta^{18} \mathrm{O}$ values of recharge were -24.1 and $-21.2 \%$ at the upland corn and lowland corn sites, respectively. These values and the trend to a lower $\delta^{18} \mathrm{O}$ value of ground water were consistent with recharge of spring infiltration that had resided in the unsaturated zone since March or April. Although rapid movement 
of irrigation water through the upper $1.6 \mathrm{~m}$ of the unsaturated zone occurred following application (Figures $4 \mathrm{~b}$ and $4 \mathrm{e}$ ), the unmixed irrigation water detected in wick samplers at 1.5 and 1.6 $m$, respectively, at the upland and lowland corn sites, must have either stopped above the water table or have comprised a minority of recharge so that it was not detected isotopically.

\section{Discussion}

\section{Recharge Water Pathways in the Unsaturated Zone}

Wetting-front movement and water level data generally indicated that recharge occurred hours to weeks after an infiltration event. However, with the exception of snow-melt water at the lowland corn and lowland woodland sites, isotopic data indicated that recharge water had a transit time in the unsaturated zone of 1.5 to 12 months (Table 3), longer than the travel time of wetting fronts through the unsaturated zone. Thus, the recharge was not composed of water from the most recent precipitation event or irrigation application. Because isotopic evidence indicated that the water that recharged the aquifer was older, most of the recharge detected in this study must have been older soil water displaced from the unsaturated zone by newer water that infiltrated into the soil. Results of more frequent sampling during infiltration tests with irrigation water on July 14-16, 1993, at the upland corn and lowland corn sites, also indicated that recharge was composed of older soil water rather than new infiltration water from the irrigation application. However, comparison of observed and modeled isotopic values indicates that soil water was usually highly mixed. Thus, displacement of older soil water did not occur following a pure piston-flow displacement model but rather a hydrid model involving displacement of mixed older soil water with new infiltration water.

While the isotopic data indicated that recharge was mostly composed of mixed older soil water that was displaced by new infiltration, water movement by preferential flow may also have occurred but gone undetected. Changes in isotopic composition at the water table between successive sample collections indicated the net isotopic composition of the recharge water during that period. The net isotopic composition, however, is a function of both the amount of recharge and the isotopic composition of that recharge. Relatively small amounts of recharge in comparison with total recharge during that month, or with an isotopic composition close to that of ambient ground water, would have had little effect on the net isotopic composition and would have been undetected. Thus, the isotopic data do not preclude some recharge by preferential flow. The exact percentage of recharge water that moved through the unsaturated zone by different mechanisms cannot be estimated using the data collected.

Preferential flow of recharge water through the unsaturated zone occurred during topographically focused recharge of snow melt at the lowland corn site in March-April 1993 and March 1994. Decreases in water table $\delta^{18} \mathrm{O}$ values (events 1 and 6, Figure 7a)particularly to a $\delta^{18} \mathrm{O}$ value of $-17 \%$, similar to snow melt, in March 1994-decreases in soil-water isotopic values (event 1, Figure 2d; following event 6, Figures $2 \mathrm{~d}$ and $2 \mathrm{e}$ ), and soil-moisture contents (event 1, Figures $2 \mathrm{c}$ and $2 \mathrm{e}$; event 6 , Figures $2 \mathrm{c}, 2 \mathrm{~d}$, and 2e) were consistent in indicating movement of snow melt water through the unsaturated zone in less than one week in 1993 and in about four hours in 1994.
Preferential flow of recharge water probably occurred during snow melt at the lowland corn site because the amount of infiltration was much greater than at other times of year. Soil water balance results indicate that the amount of infiltration during snow melt was $70 \%$ in 1993 and $250 \%$ in 1994 of the amount of water in the soil prior to snow melt. The large amount of infiltration caused soilmoisture contents to exceed the field capacity of 10 to $12 \mathrm{vol} \%$ throughout the unsaturated zone during 1994 (event 6, Figures 2c, $2 \mathrm{~d}$, and $2 \mathrm{e}$ ). Field capacities must have been exceeded at least along some preferential flowpaths in 1993 (event 1, Figures 3c and 3e). The isotopic changes following snow melt in 1993 were smaller than in 1994 because of a smaller snowpack and more gradual melting. With soil-moisture contents in excess of field capacity, rapid gravity drainage of snow melt water through the soil could occur with snow-melt water potentially having little interaction with older soil water bound more tightly to the soil matrix (Barnes and Allison 1988). For smaller infiltration events, where the volume of newer water did not cause soil-moisture contents to exceed the field capacity at all depths, water was retained by capillary forces in the soil pores and rapid preferential flow through the unsaturated zone did not occur. For typical events from rainstorms or irrigation, the amount of infiltration water was $5 \%$ to $30 \%$ of the amount of water stored in the soil. This water had a transit time of several weeks to months in the unsaturated zone, mixed extensively with older soil water, and moved gradually downward after being displaced by newer infiltration during subsequent infiltration events.

During 1993 and 1994 , the $\delta^{18} \mathrm{O}$ values of ground water increased during April after snow-melt recharge (events 2 and 7 , Figure 7a). This increase must have been due to recharge of water with $\delta^{18} \mathrm{O}$ values greater than about $-10 \%$. There are three possible sources for water with these values: individual April rainstorms undetected in the composite precipitation samples because of interstorm variation in isotopic values, soil water stored in the unsaturated zone prior to snow melt that infiltrated the previous summer, and snow melt water with $\delta^{18} \mathrm{O}$ values $>-10 \%$ generated by isotopic fractionation or sublimation during snow melt.

It is unlikely that the source of recharge water with $\delta^{18} \mathrm{O}$ values $>-10 \%$ was April rainfall. The $\delta^{18} \mathrm{O}$ values of rainfall samples collected in April were -11.9 to $-14.5 \%$, except for a sample collected on April 29, 1993, which had an $\delta^{18} \mathrm{O}$ value of $-9.5 \%$ (Figure 2b). However, the sample collected on April 29, 1993, represented only $6 \mathrm{~mm}$ of rain during April 27-29, and no wetting front was associated with this rainfall. Large amounts of interstorm variability in isotopic values of precipitation have been documented in some studies (Ingraham 1998). Therefore, individual April rainstorm(s) with $\delta^{18} \mathrm{O}$ values $>-10 \%$ could have occurred that would not be apparent from the composite precipitation samples collected, which generally reflected multiple storms. However, in April 1993, there were no substantial precipitation events causing wetting front movement through the unsaturated zone, indicating April rainfall could not have accounted for the increased $\delta^{18} \mathrm{O}$ values of recharge. During April 1994, rainstorms of $447 \mathrm{~mm}$ on April 14-15 and $453 \mathrm{~mm}$ on April 24-27 resulted in movement of wetting fronts through the unsaturated zone (Figures $2 \mathrm{c}, 2 \mathrm{~d}$, and $2 \mathrm{e}$ ). However, these rainstorms accounted for $75 \%$ of the precipitation collected in the composite sample on May 5, which had an $\delta^{18} \mathrm{O}$ value of $-12.5 \%$, implying that these rainstorms probably had values similar to that of the composite sample. Moreover, these rainstorms, while large enough to cause wetting front movement, were not large enough to cause large amounts of preferential flow, which 
would be required in order to have recharge of April rainfall during the same month.

The most plausible source of recharge water with $\delta^{18} \mathrm{O}$ values $>-10 \%$ was older soil water that infiltrated during the previous summer (Table 1). Although isotopic data were not collected in 1992, it is assumed that summer infiltration in 1992 would have had $\delta^{18} \mathrm{O}$ values greater than $-10 \%$, similar to summer infiltration in 1993 and 1994 (Tables 1 and 4). Soil water in the unsaturated zone prior to snow melt had $\delta^{18} \mathrm{O}$ values $>-10 \%$, consistent with summer infiltration. Five of the six samples collected from suction lysimeters and wick samplers on March 31, 1993, prior to snow melt, had $\delta^{18} \mathrm{O}$ values between -8 and $-9 \%$ (Figures $2 \mathrm{~d}, 3 \mathrm{c}$, and $3 \mathrm{~d}$ ). In addition, a core through the unsaturated zone collected at the upland corn site on March 24, 1994, after the beginning of soil thawing and snow melt but before the wetting front from snow melt had moved all the way through the unsaturated zone, indicated that soil water below about $1.8 \mathrm{~m}$ had $\delta^{18} \mathrm{O}$ values of -7.7 to $-10 \%$, consistent with summer infiltration water (Landon et al. 1999). In addition, the amount of water stored in the unsaturated zone prior to snow melt was more than enough to account for the amount of recharge of water with $\delta^{18} \mathrm{O}$ values greater than $-10 \%$ that occurred in April. During both 1993 and 1994, the amount of soil water stored in the unsaturated zone prior to snow melt was about $190 \mathrm{~mm}$. This stored water exceeded the amounts of recharge of $80 \mathrm{~mm}$ in 1993 and $140 \mathrm{~mm}$ in 1994, calculated from changes in soil-moisture content profiles, that occurred during the period (mostly in April) when recharge had $\delta^{18} \mathrm{O}$ values $>-10 \%$. Thus, infiltration from the previous summer was present in the unsaturated zone prior to snow melt in quantities sufficient to account for the recharge of water with $\delta^{18} \mathrm{O}$ values $>-10 \%$ during April 1993 and 1994. This recharge water from summer infiltration had a transit time in the unsaturated zone of at least six months (September 1992 to March 1993) and was displaced from the unsaturated zone by new infiltration of spring snow melt and April rainfall. Because recharge of this previous summer infiltration water occurred after rapid recharge of snow melt, some water from snow melt must have bypassed older soil water and moved through the unsaturated zone along preferential flowpaths. Thereafter, during April, the older soil water that infiltrated the previous summer was displaced from the unsaturated zone by newer infiltration. After the older water was displaced from the unsaturated zone, water from spring snow melt and April rainfall that did not move rapidly through the unsaturated zone by preferential flow immediately after snow melt constituted recharge during May to July or August (events 3 and 8, Figure 7a). Thus, in addition to the rapid movement of snow melt through the unsaturated zone, preferential flow of snow melt was also indicated by the fact that recharge during April, following snow melt, was composed of water that infiltrated during the previous summer.

It is possible that recharge with $\delta^{18} \mathrm{O}$ values $>-10 \%$ could result from isotopic fractionation during melting and sublimation of snow, although it is considered improbable. Snow melt and sublimation can cause the residual snowpack to become more enriched in heavy isotopes, resulting in the greater isotopic values of melt water as melting continues (Cooper 1998; Rodhe 1998). However, significant isotopic evolution of snow melt is not always observed in the field as a result of the many factors that influence these processes (Cooper 1998; Rodhe 1998). Apart from the uncertainty regarding whether snow melt fractionations occurred at this site, the following recharge sequence would be required to be consistent with observed isotopic data: (1) preferential flow and recharge of mostly unfractionated snow melt $\left(\delta^{18} \mathrm{O}\right.$ value $<-17 \%$ o in 1994) in March-early April (events 1 and 6, Table 1); (2) recharge of fractionated snow melt having $\delta^{18} \mathrm{O}$ values $>-10 \%$ in April (events 2 and 7, Table 1); and (3) recharge of snow melt and April rainfall (no rainfall causing infiltration in April 1993) with values $<-12 \%$ o during May-August (events 3 and 8, Table 1). This sequence is not impossible but requires a fairly complicated series of events and seems implausible given than the last snow melt should have the greatest $\delta^{18} \mathrm{O}$ values. Moreover, this explanation fails to account for what would happen to the approximately $190 \mathrm{~mm}$ of soil water with summer compositions in the unsaturated zone prior to snow melt. This summer water represents a much more plausible and available source of water with $\delta^{18} \mathrm{O}$ values $>-10 \%$. While there is not evidence to either prove or disprove snow fractionations as an explanation for the isotopic data, recharge of summer infiltration in the unsaturated zone prior to snow melt is a much simpler explanation that is consistent with all of the isotopic and nitrate data.

The interpretations of recharge water transit times and pathways based on seasonal isotopic variations in precipitation need to be tempered by awareness that some studies (Ingraham 1998) have found considerable interstorm variability in precipitation isotopic values. Interstorm variability would cause nonuniformity in the seasonal precipitation isotopic signal and uncertainty in the interpretation of soil water and ground water isotopic signals. The precipitation samples collected for this study indicated the average isotopic composition of precipitation since the last sample collection (usually monthly), and thus incorporated water from all of the storms during that month. Storms with isotopic compositions substantially different from the monthly averages were likely relatively small in magnitude and, therefore, minor or insignificant sources of ground water recharge. Ground water recharge is more likely to reflect isotopic values of water that infiltrates over a longer period of time and integrates water from multiple storms. The results of more frequent precipitation sampling during April-June 1993 indicated that isotopic values of individual rainstorms were generally similar to monthly volume-weighted averages. Therefore, the effect of interstorm variations in precipitation isotopic values on the interpretations is considered to be insignificant, but is nevertheless unknown because samples were not collected for all individual precipitation events.

\section{Recharge Water Transit Times in the Unsaturated Zone}

The transit times of seasonal isotopic signals in the unsaturated zone varied from less than one week to one year (Table 3). Transit times of less than one week were detected during recharge of snow-melt water at the lowland corn site during March or April. Minimum transit times of less than one month were also detected during fall recharge at the lowland corn site and during spring 1993 and fall 1994 recharge at the lowland wooded site (Table 3; Figure 7a). Minimum transit times for the upland corn and upland grass sites and for summer recharge at all sites were 1.5 to 3.5 months. Maximum transit times ranged from 1.5 to 12 months. The transit time values are based on the interpretation that the spring, summer, or fall seasonal isotopic signals observed at the water table represent those of the most recent spring, summer, or fall, respectively, rather than seasonal signals from previous years, which would indicate much longer transit times. This interpretation is supported by vertical soil-water isotopic profiles in cores through the unsaturated zone collected in March and August 1994 (Landon et al. 1999) that indicate the unsaturated zone contained water 
from only one seasonal cycle rather than seasonal signals from multiple years.

Transit times through the unsaturated zone of up to 12 months were longer than expected given the fine to medium-grained sand texture, relatively high hydraulic conductivity, and shallow depth to water of 2.5 to $4.5 \mathrm{~m}$. The longer transit times reflect the fact that the volume of water entering the soil during most infiltration events was generally small, $5 \%$ to $30 \%$ of the volume of water stored in the unsaturated zone. As a result, several infiltration events over a period of several months were required to replace the volume of water in the unsaturated zone. Recharge from spring infiltration generally had shorter transit times than summer infiltration (Table 3). At the lowland corn site, for instance, 1993 spring recharge had transit times in the unsaturated zone from less than one week to five months compared to 1993 summer recharge that had transit times of 3.5 to 12 months. These seasonal differences in transit time probably reflect the fact that there was a larger volume of infiltration in proportion to the volume of water in storage in the unsaturated zone during snow melt and lower evapotranspiration during the spring than summer.

Transit times differed considerably between sites. Transit times were shorter at the lowland corn site than at the upland corn site (Figure 7; Table 3). The isotopic data were consistent with the wetting-front movement and water level data, which indicated more rapid movement of wetting fronts and larger amounts of recharge at the lowland corn site than at the upland corn site (Delin et al., in press). Delin et al. (in press) attributed the greater recharge and more rapid wetting front movement to three factors: (1) surface runon of water into the local depression around the lowland corn site, especially during spring snow melt and other periods of intense or prolonged rainfall; (2) fine-grained laminations found between 1 and $2 \mathrm{~m}$ below the upland corn site but absent at the lowland corn site; and (3) coarser-grained sediments at the lowland site at depths greater than about $1 \mathrm{~m}$. A smaller average depth to the water table of $2.8 \mathrm{~m}$ at the lowland corn compared to $4.3 \mathrm{~m}$ at the upland corn site (Figure 7) also probably contributed to the more rapid transit time of recharge water through the unsaturated zone at the lowland corn site.

Because the sampling frequency was sometimes different at the lowland wooded and upland grass sites compared to the upland corn and lowland corn sites it was not always possible to compare transit times between these two groups. However, the lowland wooded and upland grass sites had the same sampling frequency, so these sites were directly comparable to each other. Transit times were generally shorter at the lowland wooded site, which had an average depth to water of $2.9 \mathrm{~m}$, than at the upland grass site, which had an average depth to water of $4.5 \mathrm{~m}$ (Table 3 ). Soil properties at the upland grass site are similar to those at the upland corn site (Tomer and Anderson 1995). Because similar data on soil properties at the lowland wooded site were not collected, the relation of soil properties and transit time cannot be determined at this site.

\section{Relation of Nitrate Concentrations to Recharge}

Increases in nitrate concentrations at the water table beneath the lowland corn site during April-May 1993 and 1994 corresponded with increased $\delta^{18} \mathrm{O}$ values, which indicated that the source of the recharge was water that infiltrated during the previous summer. This summer infiltration water was likely displaced from the unsaturated zone by water infiltrating into the soil following snow melt. It is considered unlikely that the increases in nitrate concentrations were related to nitrogen fertilizer applications occurring in April or early May. In 1993, the first application of nitrogen fertilizer was on April 28 at a rate of 22 kilograms per hectare (kg/ha) (Landon et al. 1997). Between fertilizer application and ground water sample collection on April 30 there was $1.5 \mathrm{~mm}$ of rainfall but no wetting front movement. Similarly, in 1994, the first application of nitrogen fertilizer was on May 3 at a rate of $22 \mathrm{~kg} / \mathrm{ha}$. Because there was no precipitation on May 3 this application could not have affected the ground water nitrate concentrations measured on May 3. Thus, the increases in nitrate concentrations occurred before the effects of nitrogen fertilizer applications in late April and early May of the same year could have been detected at the water table. Rather, the nitrate that reached ground water during April 1993 and 1994 was probably residual nitrate in the soil from previous years.

Increases in nitrate concentrations at the lowland corn site also occurred in July-August 1994 owing to recharge of water that infiltrated during the summer of 1994. Because of the effects of the infiltration and tracer experiments in August--October 1993, it was not possible to identify the effects of recharge of summer 1993 infiltration on nitrate concentrations. Concentrations of nitrate at the lowland corn site generally decreased when recharge was composed of water that infiltrated during the spring or fall.

Increases in ground water nitrate concentrations associated with recharge of summer infiltration probably result from summer infiltration having greater nitrate concentrations than spring or fall infiltration. Nitrogen fertilizers applied on the cropped areas (Figure 1) are the primary source of the nitrate in the upper 1 to $2 \mathrm{~m}$ of the saturated zone beneath these areas (Landon et al. 1998). Nitrogen isotope data for shallow ground water at the upland and lowland corn sites are considered to be consistent with a fertilizer source of the nitrate (Böhlke et al., submitted). Average concentrations of nitrate were $0.45 \mathrm{mg} / \mathrm{L}$ in snow and $1.7 \mathrm{mg} / \mathrm{L}$ in rain during $1992-95$ (Delin et al. 1997), indicating nitrate in precipitation is not a substantial source of nitrate in ground water. Nitrogen mineralization in the soil also should be a minor source of nitrogen at the site because of the low organic content of the soils of $1 \%$ or less (Landon et al. 1998). Because nitrogen fertilizers are primarily applied during late April to August, summer (May-September) infiltration probably has the greatest opportunity to interact with relatively high soil nitrogen concentrations and leach nitrate in comparison with spring and fall infiltration. The largest nitrate concentrations then remained with the water that flushed the nitrate out of the root zone after fertilizer application in the summer. By the following March or early April, soil nitrogen concentrations probably would be diminished by plant uptake and leaching during the subsequent 7 to 11 months and snow melt and rain water infiltrating into the soil would be in contact with relatively low soil nitrogen concentrations relative to summer infiltration, resulting in lower nitrate concentrations in spring infiltration. As a result, recharge of spring infiltration diluted ground water nitrate concentrations. Alternatively, seasonal changes in ground water nitrate concentrations could be interpreted as resulting from seasonally uniform nitrate leaching rates from the root zone with variable amounts of dilution by seasonally varying amounts of recharge. If this mechanism accounted for seasonal fluctuations in ground water nitrate concentrations, then concentrations should always have decreased when large amounts of recharge occurred and should always have increased when small amounts of recharge occurred. However, during events 2 and 7 , ground water levels, soil-moisture contents, and isotopic values indicated substantial amounts of recharge of summer infiltration, but 
ground water nitrate concentrations increased rather than decreased. Therefore, it is interpreted that the seasonal variations in ground water nitrate concentrations are primarily related to seasonal variations in nitrate concentrations in infiltration, although variable amounts of dilution probably also sometimes influenced ground water nitrate concentrations.

Nitrate concentrations were strongly influenced by the timing of infiltration with respect to nitrogen fertilizer application but were also sometimes influenced by recharge water pathways and transit times. For instance, during rapid recharge of snow melt water at the lowland corn site in March 1994, recharge water had a transit time in the unsaturated zone of hours to days and had much smaller nitrate concentrations than spring infiltration water that recharged the aquifer a few months later. The smaller nitrate concentrations were likely related to the minimal contact that snow melt water moving by preferential flow had with the soil and older soil water.

The linkage of seasonal recharge and nitrate concentrations was most clearly evident at the lowland corn site, owing to the locally rapid movement of recharge water. Temporal variations in nitrate concentrations at the upland corn site were subdued and delayed compared with those at the lowland corn site owing to slower movement of recharge water. However, nitrate concentrations increased slightly at the upland corn site during recharge of 1994 summer infiltration.

\section{Conclusions}

Stable-isotope data indicated that ground water recharge had transit times that varied from less than one week to about 12 months through a sandy unsaturated zone with average depths to the water table of 2.8 to $4.5 \mathrm{~m}$. Transit times of less than one week were detected in a topographic depression in a corn field where isotopic and soil-moisture content data indicated that rapid movement of snow melt water to the water table occurred by preferential flow. At all other sites and times, the ground water recharge was composed of water that had transit times in the unsaturated zone of several weeks to months and was displaced by new water infiltrating into the unsaturated zone. However, comparison of the isotopic values of soil water to simulated values from pure-piston flow and mixing-cell water and isotopic mass balance models indicate that the soil water was usually highly mixed. Thus, a hybrid piston-type model where mixed older soil water was displaced by new infiltration water seems to be the predominant mechanism for the movement of the recharge water through the unsaturated zone.

Increases in ground water nitrate concentrations at the lowland corn and upland corn sites were associated with recharge of water that infiltrated into the soil during the summer. Thus, the greatest nitrate concentrations remained with the water that flushed the nitrate out of the root zone after fertilizer application. Recharge of summer infiltration water with relatively large nitrate concentrations occurred primarily during two periods annually at the lowland corn site: (1) during the late summer and early fall, two to six months after infiltration, and (2) during the following spring and early summer, seven to 12 months after infiltration, as this water was displaced from the unsaturated zone by spring infiltration.

The relatively long transit times of recharge water in the unsaturated zone were in direct contrast to the comparatively rapid movement of wetting fronts through the unsaturated zone, generally in hours to weeks. Although monitoring of wetting-front movement indicated when recharge occurred it did not indicate the tran- sit time of the recharged water. Stable-isotopic data are useful in studying contaminant transport through the unsaturated zone in sandy soils because they provide a direct measure of recharge water transit time and link nitrate concentrations to infiltration timing.

\section{Acknowledgments}

We thank U.S. Geological Survey reviewers J.K. Böhlke and P.M. Jones and reviewers at the journal for their helpful comments on this manuscript. This study was a cooperative effort between the U.S. Geological Survey and the Minnesota Pollution Control Agency. This study was carried out in close cooperation with studies funded by the Toxics Substances Hydrology Program of the U.S. Geological Survey. We also wish to the U.S. Department of Agriculture-Agricultural Research Service and the University of Minnesota, Department of Soil, Water, and Climate, for their cooperation at the Minnesota Management Systems Evaluation Area.

The use of trade or product names in this report is for identification purposes only and does not constitute endorsement by the U.S. Geological Survey (USGS).

Editor's Note: The use of brand names in peer-reviewed papers is for identification purposes only and does not constitute endorsement by the authors, their employers, or the National Ground Water Association.

\section{References}

Baker, D.G., W.W. Nelson, and E.L. Kuehnast. 1979. Climate of Minnesota Part XII, The hydrologic cycle and soil and water. University of Minnesota Agricultural Experiment Station Technical Bulletin. St. Paul, Minnesota.

Baker, D.G., E.L. Kuehnast, and J.A. Zandlo. 1985. Climate of Minnesota Part XV, Normal temperatures (1951-80) and their application. University of Minnesota Agricultural Experiment Station Report $A D-S B$-2777. St. Paul, Minnesota.

Barnes, C.J., and G.B. Allison. 1988. Tracing of water movement in the unsaturated zone using stable isotopes of hydrogen and oxygen. Journal of Hydrology 100, 143-176.

Bengtsson, L., R.K. Saxena, and Z. Dressie. 1987. Soil water movement estimated from isotope tracers. Journal of Hydrological Sciences 32, no. 4: 497-520.

Böhlke, J.K., R. Wanty, M. Tuttle, G.N Delin, and M.K Landon. Submitted. Chronology and isotope geochemistry of a transient agricultural nitrate plume undergoing denitrification beneath a field-wetlandstream transect in a glacial sand-plain aquifer, Minnesota. Water Resources Research.

Bowman, R.S., and R.C. Rice. 1986. Transport of conservative tracers in the field under intermittent flood irrigation. Water Resources Research 22, no. 11: 1531-1536.

Brown, K.W., J.C. Thomas, and M.W. Holder. 1986. Development of a capillary wick unsaturated zone water sampler. Cooperative agreement CR812316-01-0, U.S. Environmental Protection Agency. Las Vegas, Nevada: Environmental Monitoring Systems Laboratory.

Burns, D.A., P.S. Murdoch, G.B. Lawrence, and R.L. Michel. 1998. Effect of groundwater springs on $\mathrm{NO}^{-}$concentrations during summer in Catskill Mountain streams. Water Resources Research 34, no. 8: 1987-1996.

Cooper, L.W. 1998. Isotopic fractionation in snow cover. In lsotope Tracers in Catchment Hydrology, ed. C. Kendall and J.J. McDonnell, 119-136. New York: Elsevier.

Coplen, T.B. 1993. Uses of environmental isotopes. In Regional GroundWater Quality, ed. W.M. Alley, 227-254. New York: Van Nostrand Reinhold

Darling, W.G., and A.H. Bath. 1988. A stable isotope study of recharge processes in the English Chalk. Journal of Hydrology 101, 31-46. 
Delin, G.N., and M.K. Landon. 1996. Effects of topography on the transport of agricultural chemicals near Princeton, Minnesota, 1992. U.S. Geological Survey Toxic Substances Hydrology ProgramProceedings of the Technical Meeting, Colorado Springs, Colorado, September 20-24, 1993, ed. D.W. Morganwalp and D.A. Aronson. U.S. Geological Survey Water-Resources Investigations Report 944015, vol. 1: $555-564$.

Delin, G.N., R.W. Healy, M.K. Landon, and J.K. Böhlke. In press. Effects of topography and soil properties on recharge at two sites in an agricultural field. Journal of the American Water Resources Association.

Delin, G.N., M.K. Landon, R.W. Healy, and H.W. Olsen. 1996. Spatial variability of unsaturated-zone properties in relation to topography in a sand-plain setting near Princeton, Minnesota. U.S. Geological Survey Toxic Substances Hydrology Program-Proceedings of the Technical Meeting, Colorado Springs, Colorado, September 20-24, 1993, ed. D.W. Morganwalp and D.A. Aronson. U.S. Geological Survey Water-Resources Investigations Report 94-4015, vol. 1: 565-574.

Delin, G.N., M.K. Landon, J.A. Lamb, and J.L. Anderson. 1994. Characterization of the hydrogeology and water quality at the Management Systems Evaluation Area near Princeton, Minnesota, 1991-92. U.S. Geological Survey Water-Resources Investigations Report 94-4149.

Delin, G.N., M.K. Landon, K.J. Nelson, R.B. Wanty, R.W. Healy, H.W. Olsen, J.K. Bohlke, B.R. Shroyer, and P.D. Capel. 1997. Hydrogeologic and water-quality data used to evaluate the effects of focused recharge on ground-water quality near Princeton, Minnesota, 1991-95. U.S. Geological Survey Open-File Report 97-21.

Fedkiw, J. 1991. Nitrate occurrence in U.S. waters (and related questions) A reference summary of published sources from an agricultural perspective. Washington, D.C. USDA Working Group of Water Qualty, U.S. Department of Agriculture.

Fortin, G., G. van de Kamp, and J.A. Cherry. 1991. Hydrogeology and hydrochemistry of an aquifer-aquitard system within glacial deposits, Saskatchewan, Canada. Journal of Hydrology 126, no. 1: 265-292.

Gamble, B.F., Y. Eckstein, and W.M. Edwards, 1990a. Principles of evaluation of soil water residence time using queueing disciplines with water budget data (theoretical background-I). Journal of Hydrology $113,1-25$.

Gamble, B.F., Y. Eckstein, and W.M. Edwards. 1990b. Evaluation of soil water residence time in a monolith lysimeter from the application of using queueing disciplines to water budget data (demonstration - II). Journal of Hydrology 113, 27-49.

Gat, J.R. 1981. Groundwater. In Stable Isotope Hydrology, ed. J.R. Gat and R. Gonfiantini, 223-240. Vienna: International Atomic Energy Agency.

Gat, J.R., and Y. Tzur. 1967. Modification of the isotopic composition of rainwater by processes which occur before groundwater recharge. In Isotopes in Hydrology, Proceedings of the Symposium on Isotopes in Hydrology, International Atomic Energy Agency in Cooperation with the International Union of Geodesy and Geophysics, Vienna, Austria, November 14-18, 1966: 49-60. Vienna: IAEA.

Hallberg, G.R. 1989. Nitrate in ground water in the United States. In Nitrogen Management and Ground Water Protection, Developments in Agricultural and Managed-Forest Ecology 21, ed. R.F. Follett, 35-74. New York: Elsevier.

Ingraham, N.L. 1998. Isotopic variations in precipitation. In Isotope Tracers in Catchment Hydrology, ed. C. Kendall and J.J. McDonnell, 87-118. New York: Elsevier

International Atomic Energy Agency. 1981. Stable isotope hydrology, deuterium and oxygen-18 in the water cycle. Technical Reports Series no. 210. Vienna, Austria: IAEA.

Jackson, T. 1991. Written communication, October 15, U.S. Department of Agriculture, Elk River, Minnesota.

Komor, S.C., and D.G. Emerson. 1994. Movement of water, solutes, and stable isotopes in the unsaturated zones of two sand plains in the upper Midwest. Water Resources Research 30, $253-267$.

Landon, M.K., G.N. Delin, K.J. Nelson, C.P. Regan, J.A. Lamb, S.J. Larson, P.D. Capel, J.L. Anderson, and R.H. Dowdy. 1997. Waterquality and hydrogeologic data used to evaluate the effects of farming systems on ground-water quality at the Management Systems Evaluation Area near Princeton, Minnesota, 1991--95. U.S. Geological Survey Open-File Report 97-22.
Landon, M.K., G.N. Delin, J.A. Lamb, J.L. Anderson, and R.H. Dowdy. 1998. Effects of farming systems on ground-water quality at the Management Systems Evaluation Area near Princeton, Minnesota, 1991-95. U.S. Geological Survey Water-Resources Investigations Report 98-4128.

Landon, M.K., G.N. Delin, S.C. Komor, and C.P. Regan. 1999. Comparison of the stable-isotopic composition of soil water collected from suction lysimeters, wick samplers, and cores in a sandy unsaturated zone. Journal of Hydrology 224, 45-54.

Lindstrom, G., and A. Rodhe. 1992. Transit times of water in soil lysimeters from modeling of oxygen-18. Water, Air, and Soil Pollution 65, 83-100.

Mathieu, R., and T. Bariac. 1996. An isotopic study $\left({ }^{2} \mathrm{H}\right.$ and $\left.{ }^{18} \mathrm{O}\right)$ of water movements in clayey soils under a semiarid climate. Water Resources Research 32, 779-789.

Meyboom, P. 1966. Unsteady groundwater flow near a willow ring in hummocky moraine. Journal of Hydrology 4, 38-62.

Miller, J.J., D.F. Acton, and R.J. St. Arnaud. 1985. The effect of groundwater on soil formation in an morainal landscape in Saskatchewan. Canadian Journal of Soil Science 65, 293-307.

Mullin, A.H. 1995. Written communication, September 13, U.S. Geological, Survey, Denver, Colorado.

Payne, B.R. 1988. The status of isotope hydrology today. Journal of Hydrology 100, 207-237.

Puckett, L.J. 1995. Identifying major sources of nutrient water pollution. Env. Sci. and Tech. 29, no. 9: 408a-414a.

Reicosky, D.C., J.A. Lamb, and R.H. Dowdy. 1995. Impact of crop water use on groundwater quality. In Clean Water-Clean Environment-21st Century: Practices, Systems \& Adoption, Conference Proceedings 3, 211-214. St. Joseph, Michigan: Am. Soc. Agri. Eng.

Rodhe, A. 1998. Snowmelt-dominated systems. In Isotope Tracers in Catchment Hydrology, ed. C. Kendall and J.J. McDonnell, 391-433. New York: Elsevier.

Saxena, R.K. 1984. Seasonal variations of oxygen-18 in soil moisture and estimation of recharge in esker and moranic formations. Nordic Hydrology 15, 235-242.

Sharma, M.L., P. Farrington, and M. Fernie. 1983. Localized groundwater recharge on the "Gnangara Mound." In Western Australia Int. Conf. on Groundwater and Man, Sydney, N.S.W., vol. 1: The Investigation and Assessment of Groundwater Resources, 293-302. Canberra, A.C.T., Australia: Australian Water Resources Council.

Stewart, M.K., and J.J. McDonnell. 1991. Modeling base flow soil water residence times from deuterium concentrations. Water Resources Research 27, no. 10: 2681-2693.

Tomer, M.D., and J.L. Anderson. 1995. Variation of soil water storage across a sand plain hillslope. Soil Science Society of America Journal 59, no. 4: 1091-1100.

Topp, G.C., J.L. Davis, and A.P. Annan. 1980. Electromagnetic determination of soil water content measurements in coaxial transmission lines. Water Resources Research 16, no. 3: 574-582.

U.S. Department of Commerce. 1961-92. Minnesota annual summary reports. National Oceanic and Atmospheric Administration. Asheville, North Carolina.

Wenner, D.B., P.D. Ketcham, and J.F. Dowd. 1991. Stable isotopic composition of waters in a small Piedmont watershed. In Stable Isotope Geochemistry: A Tribute to Samuel Epstein, The Geochemical Society, Special Publication No. 3, ed. H.P. Taylor Jr., J.R. O'Neil, and I.R. Kaplan, 195-203. San Antonio, Texas: Geochemical Society.

Yurtsever, Y. 1983. Models for tracer data analysis. Guidebook on Nuclear Techniques in Hydrology. Technical Report 91, 381-402. Vienna, Austria: IAEA.

Yurtsever, Y., and J.R. Gat. 1981. Stable isotope hydrology, deuterium and oxygen-18 in the water cycle. Technical Report 210 , Chapter 6. Vienna, Austria: IAEA.

Zimmerman, U., D. Ehhalt, and K.O. Munnich. 1967. Soil-water movement and evapotranspiration: changes in the isotopic composition of the water. In Isotopes in Hydrology, Proceedings of the Symposium, International Atomic Energy Agency, Vienna, Austria, November 1418, 1966: 567-585. Vienna: IAEA. 